\title{
THE ADEQUACY OF INTERNATIONAL LEGAL OBLIGATIONS FOR ENVIRONMENTAL PROTECTION DURING ARMED CONFLICT ${ }^{1 *}$
}

\author{
Arie Afriansyah ${ }^{2 * *}$
}

\begin{abstract}
Since it first developed, the law of war has focused on protecting human beings. It prioritises human protection by controlling the conduct of belligerents in order to minimise human injuries and casualties. However, the consequences of war are seldom limited to human casualties. War also causes major destruction to the environment. This article shows that despite prioritising human protection, international law provides a significant number of rules to protect the environment during armed conflicts. Contrary to claims that existing rules are insufficient, the law of war adequately safeguards the environment during armed conflicts by prohibiting certain military activities that may cause significant damage to the environment. Furthermore, there are peacetime regulations that may continue to bind belligerents in times of war.
\end{abstract}

Keywords: environmental protection, international armed conflict, legal obligations.

\section{Introduction}

Since it first developed, the law of war has focused on protecting human beings. ${ }^{3}$ It prioritises human protection by controlling the conduct of belligerents in order to minimise human injuries and casualties. ${ }^{4}$ However, the consequences of war are seldom limited to human casualties. War also causes major destruction to the environment. ${ }^{5}$

This article shows that despite prioritising human protection, international law provides a significant number of rules to protect the environment during armed conflicts. Contrary to claims that existing rules are insufficient, ${ }^{6}$ the law of war adequately safeguards the environment during

\footnotetext{
1 *Paper was presented at the 3rd CILS International Conference on Human Security, 26-27 November 2012, Faculty of Law, Hasanuddin University, Makassar, Indonesia.

${ }^{2 * *}$ Lecturer, Faculty of Law University of Indonesia; Ph.D. Candidate, Faculty of Law University of Otago, New Zealand. The author can be reached at arie.afriansyah@ui.ac.id or arieafriansyah@gmail.com.

${ }^{3}$ APV Rogers Law on the Battlefield (2nd ed, Manchester University Press, Manchester, 2004) at 163.

${ }^{4}$ Yoram Dinstein The Conduct of Hostilities under the Law of International Armed Conflict (Cambridge University Press, Cambridge, 2004)at 16-20.

${ }^{5}$ Katherine M. Kelly "Declaring War on the Environment: The Failure of International Environmental Treaties during the Persian Gulf War" (1991) 7Am. U. J. Int'l L. \& Pol'y 921 at 922-927.

${ }^{6}$ This argument was raised during the event of the Gulf War in 1990s. See also Adam Roberts "The Law of War and Environmental Damage" in: Jay E. Austin and Carl E. Bruch (eds) The Environmental Con-
} 
armed conflicts by prohibiting certain military activities that may cause significant damage to the environment. Furthermore, there are peacetime regulations that may continue to bind belligerents in times of war. These peacetime obligations significantly strengthen the legal protection given to the environment during armed conflicts. ${ }^{7}$ Relevant peacetime provisions may be found in international human rights law, international environmental law and international law of the use of force (ius ad bellum).

In identifying the relevant legal rules, this article draws on international conventions (treaty law) and international custom (customary international law), as well as making reference to general principles of law, judicial decisions and eminent literature as additional sources of law. ${ }^{8}$

This article firstly examines states' obligations under international humanitarian law (IHL) and then analyses peacetime obligations. It shows clearly that existing legal obligations that protect the environment during wartime are adequate, and thus that belligerent states can potentially be held liable if these rules are violated.

\section{Does International Humanitarian Law (the Law of War) Provide Suf- ficient Rules to Protect the Environment?}

Some commentators divide environmental protection within the law of war into two categories: direct and indirect protection. Such a distinction is based on the intention of the drafters or the ratio behind the specific rule: those that were specifically intended to protect the environment; and those that were not intended to do so, but may nevertheless be favourable to environmental protection. ${ }^{9}$

Nevertheless, both of these categories are equally important for the purposes of this thesis because they have the same effect: protecting the environment during armed conflict (although this may be to a greater or lesser degree in the individual case). Examining all rules within the law of war that protect the environment during armed conflicts, whether directly or indirectly, is necessary in order to demonstrate that international law provides sufficient legal protection for the environment in wartime.

\section{A. Treaty Law}

There are a number of treaty provisions within the law of war that address environmental protection in times of armed conflict. ${ }^{10}$ This section dis-

\footnotetext{
sequences of War (Cambridge University Press, Cambridge, 2000) 47 at 66.

7 See Alice Louise Bunker "Protection of the Environment during Armed Conflict: One Gulf, Two Wars" (2004) 13RECIEL 201 at 202-203.

8 ICJ Statute, art. 38(2).

${ }^{9}$ Erik Koppe The Use of Nuclear Weapons and the Protection of the Environment during International Armed Conflict (Hart, Oxford, 2008) at 122-308.

${ }^{10}$ These provisions come from treaties such as the 1907 Hague Regulations Respecting the Laws and Customs of War on Land, the 1925 Protocol for the Prohibition of the Use in War of Asphyxiating, Poisonous or other Gases, and of Bacteriological Methods of Warfare, the 1949 Geneva IV Convention relative to the Protection of Civilian Persons in Time of War, the 1977 Convention on the Prohibition of Military or Any Other Hostile Use of Environmental Modification Techniques (ENMOD), the 1977 Protocol Additional to the Geneva Conventions of 12 August 1949, and relating to the Protection of Victims of International
} 
cusses those provisions separately and chronologically, and shows that awareness of the need to specifically protect the environment in times of war arose in the 1970s, as part of the worldwide environmental movement. In addition, it will be shown that the environment during wartime may be protected simply as an adjunct to protecting people and their property or can be protected in its own right or due to its own inherent value.

\section{The 1907 Hague Regulations Respecting the Laws and Customs of War on Land ${ }^{11}$}

This treaty protects the environment during armed conflict through art 23(g), which proscribes acts that 'destroy or seize the enemy's property, unless such destruction or seizure be imperatively demanded by the necessities of war', 12 and art 55, which obliges occupying powers to 'safeguard the capital' of 'properties (real estate, forests and agricultural estates), and administer them in accordance with the rules of usufruct.1.13

Although mainly intended to safeguard human survival, art 23(g)'s reference to human 'property' potentially includes the environment. ${ }^{14}$ Thus, some scholars consider that this article provides protection for the environment in terms of natural resources that are state property, such as oil stations or refineries that may become military targets of a war. ${ }^{15}$ Furthermore, art 55 explicitly mentions that forests and agricultural estates are to be protected because of their indispensable value in supporting human life. This obligation was applied after the Second World War to hold German industrialists accountable for over-exploiting Polish forests for timber during the period of occupancy. ${ }^{16}$

While it is true that art 23(g) provides an escape clause for military necessity, the provision as a whole gives notice to warring parties to take into account environmental factors during hostilities. Even though it was created without specific consideration of the environment, this provision has been argued by a commentator to offer protection in situations of 'extreme acts of environmental degradation. ${ }^{17}$

Armed Conflicts (Protocol 1), the 1981 Certain Conventional Weapons Convention, especially the Third Protocol on Incendiary Weapons and the 1998 Statute of the International Criminal Court.

11 The 1907 Hague Convention (IV) Respecting the Laws and Customs of War on Land (opened for signature 18 October 1907, entered into force 26 January 1910), annex [the 1907 Hague Regulations].

12 Ibid, art 23(g).

13 Ibid, art 55. According to Black's Law Dictionary, usufruct means "a right for a certain period to use and enjoy the fruits of another's property without damaging or diminishing it, but allowing for any natural deterioration in the property over time". Bryan A. Garner Black's Law Dictionary (9th ed, St. Paul, West, 2009) at 1684.

${ }^{14}$ Koppe, above n 9, at 283.

15 Luan Low and David Hodgkinson "Compensation for Wartime Environmental Damage: Challenges to International Law after the Gulf War" (1995) 35 Va. J. Int'l L. 405 at 438; Aaron Schwabach "Environmental Damage Resulting from the NATO Military Action against Yugoslavia" (2000) 25 Colum. J. Envtl L. 117 at 124 .

16 Richard A. Falk Revitalizing International Law (Iowa State University Press, Ames, 1989) at 171-172; Mark J.T. Caggiano "The Legitimacy of Environmental Destruction in Modern Warfare: Customary Substance Over Conventional Form" (1993) 20 B. C. Envtl Aff. L. Rev. 479 at 486-487.

${ }^{17}$ Richard G. Tarasofsky "Legal Protection of the Environment during International Armed Conflict" (1993) 24 NYIL 17 at 42. 
2. The 1925 Geneva Protocol for the Prohibition of the Use in War of Asphyxiating, Poisonous or other Gases, and of Bacteriological Methods of Warfare

This Protocol prohibits the use of 'asphyxiating, poisonous or other gases, and of all analogous liquids materials or devices' during hostilities. ${ }^{18}$ The Protocol has been acknowledged as providing a valuable norm that enhances the protection of humans and the environment during armed conflict. ${ }^{19}$

Poisonous weapons are available due to the rapid progress of technology and threaten not only humans but also the environment. ${ }^{20}$ The use of chemical weapons brings indiscriminate consequences. These chemicals can have enduring destructive effects on natural ecosystems ${ }^{21}$ and can be transmitted throughout the food chain. ${ }^{22}$ The adoption of the 1925 Protocol was triggered by the atrocious experiences of the First World War, when applications of poison gases caused devastating casualties to both humans and wildlife. ${ }^{23}$ But even before this, the use of poison gas in warfare had been denounced by a declaration ${ }^{24}$ and prohibited by a convention. ${ }^{25}$

Despite two broad concerns of lack precise definitions of the weapons that are prohibited and a significant number of states' reservations on applicability based on a reciprocal basis, ${ }^{26}$ it is contended that such concerns are outweighed by certain positive developments. First, in the absence of a precise definition of the prohibited weapons, the United Nations General Assembly (UNGA) has clarified the scope of the 1925 Protocol. ${ }^{27}$ Second, despite providing for reservations, the Protocol has been 'relatively well observed', ${ }^{28}$

${ }^{18}$ Geneva Protocol for the Prohibition of the Use in War of Asphyxiating, Poisonous or Other Gases, and of Bacteriological Methods of Warfare (opened for signature 17 June 1925, entered into force 8 February 1928).

${ }^{19}$ Tarasofsky, above n 17, at 55.

${ }^{20}$ Hector Gros Espiell “Commentary: 1925 Geneva Protocol for the Prohibition of the Use in War of Asphyxiating, Poisonous or other Gases, and of Bacteriological Methods of Warfare" in N. Ronzitti (ed) The Law of Naval Warfare (Kluwer Academic Publishers, Boston, 1988) 409 at 420.

21 Bernard K. Schafer "The Relationship between the International Laws of Armed Conflict and Environmental Protection: The Need to Re-evaluate What Types of Conduct are Permissible during Hostilities” (1988) 19 Cal. W. Int'l L. J. 287 at 302.

22 Michael N. Schmitt "Green War: An Assessment of the Environmental Law of International Armed Conflict”(1997) 22 Yale J. Int'l L. 1 at 86.

${ }^{23}$ It was noted that the use of chemical weapons during World War I caused about 1.3 million human casualties. Kevin J. Fitzgerald "The Chemical Weapons Convention: Inadequate Protection From Chemical Warfare" (1997) 20 Suffolk Transnat'l L. Rev. 425 at 429; David B. Merkin "The Efficiency of Chemical Arms Treaties in the Aftermath of the Iran-Iraq War" (1991) 9 B. U. Int'l L. J. 175 at 176; David A. Koplow "Long Arms and Chemical Arms: Extraterritoriality and the Draft Chemical Weapons Convention" (1990) 15 Yale J. Int'l L.1 at 8;Schwabach, above n 15, at 124.

24 Hague Declaration (IV, 2) on the Use of Projectiles the Object of Which is the Diffusion of Asphyxiating or Deleterious Gases (opened for signature 29 July 1899, entered into force 4 September 1900).

${ }^{25}$ The 1907 Hague Regulations, above n 11. Article 23(a) prohibits states "employ[ing] poison or poisoned weapons".

${ }^{26}$ Tarasofsky, above n 17, at 55-56; Espiell, above n 20, at 422.

${ }^{27}$ The UNGA stated that the Protocol prohibited use of: "(a) any chemical agents of warfare--chemical substances, whether gaseous, liquid or solid--which might be employed because of their direct toxic effect on man, animals or plants; (b) any biological agents of warfare--living organisms, whatever their nature, or infective material derived from them--which are intended to cause disease or death in man, animals, or plants, and which depend for their effect on their ability to multiply in the person, animal or plant attacked". Question of Chemical and Bacteriological (Biological) Weapons GA Res 2603, XXIV (1969) [UNGA Res 2603].

${ }^{28}$ Tarasofsky, above n 17, at 56. 
and the use of poison gas has been frequently 'condemned as a violation of international law'. ${ }^{29}$ This is likely because the implementation of the Protocol has not been solely based on a relatively altruistic recognition of these weapons' inherently devastating effects, but on reciprocity. That is, states observe the Protocol, to a significant degree, out of the fear that otherwise these weapons would be used more readily against them. ${ }^{30}$ But rather than undermining the Protocol's effectiveness, as a matter of state practice, this reciprocity basis has enhanced the effective implementation of this Protocol. ${ }^{31}$ Third, the Protocol has been successfully argued to apply in real-life cases.For example, the use of herbicides and defoliants by the US during the Vietnam War, and Iraq's action of spilling and burning huge amounts of oil to produce black fumes during the Gulf War, have been seen as violations of the Protocol. ${ }^{32}$

\section{The 1949 Geneva IV Convention relative to the Protection of Civilian Per- sons in Time of War ${ }^{33}$}

A few years after the end of World War II in 1949, states successfully codified almost all of the rules and customs of warfare into four main conventions. ${ }^{34}$ One of these, the Fourth Convention, provides environmental protection during armed conflict. Although the Convention's principal protection is for civilian persons, there are two provisions that protect the environment as the property of individual persons. Articles 53 and 147 state, respectively, that: ${ }^{35}$

[a]ny destruction by the occupying power of real or personal property belonging individually or collectively to private persons, or to the state, or to other public authorities, or to social or co-operative organisations, is prohibited, except where such destruction is rendered absolutely necessary by military operations.

[g]rave breaches, to which the preceding Article relates, shall be those involving any of the following acts, if committed against persons or property protected by the present Convention: ... extensive destruction and appropriation of property, not justified by military necessity and carried out unlawfully and wantonly.

Article 53 closely mirrors art 55 of the Hague Regulations: ${ }^{36}$ both protect 'property' during military occupation. Article 53 is wider in that it includes not only property owned by the state but also that owned by private entities. Still, both provisions protect only those properties within national territory and leave the areas in the commons outside a state's jurisdiction unprotected. ${ }^{37}$

\footnotetext{
${ }^{29}$ Schwabach, above n 15 , at 124 .

${ }^{30}$ Espiell, above n 20, at 422 .

${ }^{31}$ Tarasofsky, above n 17 , at 56 .

${ }^{32}$ Richard M. Whitaker "Environmental Aspects of Overseas Operations" (1995) 25(4) Army Law. 27, at 33; Schwabach, above n 15, at 124; Margaret T. Okorodudu-Fubara "Oil in the Persian Gulf War: Legal Appraisal of an Environmental Warfare” (1991) 23 St Mary’s L. J. 125, at 190-191.

${ }^{33}$ Convention (IV) relative to the Protection of Civilian Persons in Time of War (opened for signature 12 August 1949, entered into force 21 October 1950) [Fourth Geneva Convention].

${ }^{34}$ The Four 1949 Geneva Conventions (opened for signature 12 August 1949, entered into force 21 October 1950) [the Four 1949 Geneva Conventions].

${ }^{35}$ Fourth Geneva Convention, above n 33, arts 53 and 147 respectively.

${ }^{36}$ Discussed above from [2.1.1].

37 Jessica C. Lawrence and Kevin Jon Heller "The First Ecocentric Environmental War Crime: The Limits of Article 8(2) of the Rome Statute" (2007) 20 Geo. Int'l Envtl L. Rev. 61 at 66.
} 
Article 53's exception for military necessity arguably sets a higher standard than the similar exception under art 23(g) of the 1907 Hague Regulation. ${ }^{38}$ This increases the level of environmental protection during military occupation, a period when destruction of the environment frequently occurs. ${ }^{39}$

Article 147 enhances art 53's environmental protection by affirming as a breach of the Convention the unlawful and wanton destruction and appropriation of property in the absence of military necessity. Significantly, art 146 requires state parties to pass domestic legislation in order to prosecute those who commit or order action amounting to a grave breach. Further, states are required to prosecute such offenders before their courts regardless of their nationality. The Convention also authorises states to hand over offenders to other states subject to any extradition agreement existing between them. ${ }^{40}$ This provision has heightened the deterrent effect on individuals involved in armed conflicts. ${ }^{41}$

4. The 1977 Convention on the Prohibition of Military or any other Hostile Use of Environmental Modification Techniques ${ }^{42}$ (ENMOD)

Inspired by the devastating experience of the American defoliation campaigns during the Vietnam War and by growing concerns over technological developments allowing states to use catastrophic environmental change as a weapon in armed conflicts, ${ }^{43}$ states in 1977 agreed to two special conventions addressing environmental protection during armed conflict. These are the Convention on the Prohibition of Military or Any Other Hostile Use of Environmental Modification Techniques (ENMOD) ${ }^{44}$ and the Protocol Additional to the Geneva Conventions of 12 August 1949 relating to the Protection of Victims of International Armed Conflicts (the 1977 Additional Protocol I) ${ }^{45}$

ENMOD generally proscribes the use of environmental modification techniques as weapons during armed conflict. The Convention also regulates the application of environmental modification technology for non-hostile purposes. It is accompanied by a document of 'Understandings', which contains written interpretations of arts I, II, III and VIII. ${ }^{46}$ Although not binding, this document is recognised as being important and relevant in terms of the interpretation of specific terms in these articles. ${ }^{47}$

${ }^{38}$ In art 53, destruction is permissible if it is rendered "absolutely necessary" by military necessity. Meanwhile, art 23(g) permits destruction if considered "imperatively demanded" by military necessity. Tarasofsky, above n 17, at 43.

${ }^{39}$ Schmitt, above n 22, at 66.

${ }^{40}$ Fourth Geneva Convention, above n 33, art 146.

${ }^{41}$ Schmitt, above $\mathrm{n} 22$, at 67.

${ }^{42}$ Convention on the Prohibition of Military or Any Other Hostile Use of Environmental Modification Techniques (opened for signature 18 May 1977, entered into force 5 October 1978) [ENMOD].

${ }^{43}$ LiesbethLijnzaad and Gerard J. Tanja "Protection of the Environment in Times of Armed Conflict: The Iraq-Kuwait War"(1993) 40 NILR 169 at 186.

${ }^{44}$ ENMOD, above $\mathrm{n} 42$.

${ }^{45}$ Additional Protocol to the Geneva Conventions of 12 August 1949, and Relating to the Protection of Victims of International Armed Conflicts (opened for signature 12 December 1977, entered into force 7 December 1978) [the 1977 Additional Protocol I].

${ }^{46}$ Report of the Conference of the Committee on Disarmament Volume I A/31/27 Supp. No. 27 (1976) [ENMOD Understandings] at [91-92]

${ }_{47}$ These Understandings were not incorporated into the Convention but became part of the negotiating record and were included in the report transmitted by the Conference of the Committee on Disarmament to the UNGA in September 1976. Koppe, above n 9, at 128-129. 
The Convention begins with art I's obligations on member states 'not to engage in military or any other hostile use of environmental modification techniques having widespread, long-lasting or severe effects as the means of destruction, damage or injury to any other state party' and not to 'assist, encourage or induce any state, group of states or international organisation to engage in activities contrary to the provisions of paragraph 1 of this article'.48 Article II specifies that 'environmental modification techniques' includes "any technique for changing - through the deliberate manipulation of natural processes - the dynamics, composition or structure of the Earth, including its biota, lithosphere, hydrosphere and atmosphere, or of outer space"..$^{49}$ Article III allows environmental modification techniques to be used only for peaceful purposes and consistently with the general principles and applicable rules of international law. ${ }^{50}$

The scope of arts I and II of ENMOD was challenged during the 1991 Gulf War after oil wells were burned and oil was spilled into the Persian Gulf by Iraqi forces. Some states were disappointed that these articles did not effectively cover these events. One of the reasons for this concern was articulated by Jordan, arguing that ENMOD contains "broad and vague" terms and impossible to enforce because it does not provide proper mechanismsfor the investigation and settlement of any dispute under the Convention. Therefore, as ENMOD "was revealed as being painfully inadequate during the Gulf conflict", Jordan proposed a revision of the existing laws protecting the environment during armed conflict through the UNGA. ${ }^{51}$

States furtherdiscussed ENMOD's failure to apply during the Gulf War at ENMOD's Second Review Conference in 1992, which considered whether or not conventional technology measures, such as the use of herbicides and burning of oil wells, fall within the scope of art II. This conference declared the use of herbicides to be a method of war proscribed under arts I and II, but unfortunately said nothing about burning oil wells. ${ }^{52}$ Nevertheless, this conclusion is an important confirmation that this Convention not only applies

${ }^{48}$ ENMOD, above $\mathrm{n} 42$, art I.

49 Ibid, art II.The "Understandings Regarding the Convention" provides a non-exhaustive list of the types of phenomena which may result from technology to modify the environment. These phenomena include: earthquakes and tsunamis; an upset in the ecological balance of a region; changes in weather patterns (clouds, precipitation, cyclones of various types and tornado storms); changes in climate patterns; changes in ocean currents; changes in the state of the ozone layer; and changes in the state of the ionosphere. ENMOD Understandings, above n 46, relating to art II. Even though these phenomena are listed, some of them are still considered to have a "high futuristic and science-fiction calibre" and may beyond the states' real capabilities. Koppe, above n 9, at 130; Dinstein, above n 2, at181.Indeed, the US and Soviet Union delegates admitted at the time ENMOD was negotiated that these techniques were only hypothetically possible. Koppe, ibid; ENMOD Understandings, above n 46, at [73-74].

${ }^{50}$ ENMOD, above $\mathrm{n} 42$, art III.

${ }^{51}$ Request for the Inclusion of an Additional Item in the Provisional Agenda of the Forth-sixth Session; Exploitation of the Environment as a Weapon in Times of Armed Conflict and the Taking of Practical Measures to Prevent Such Exploitation; Note verbale dated 5 July 1991 from the Chargé d'affairesa.i. of the Permanent Mission of Jordan to the United Nations addressed to the Secretary-General A/46/141 (1991) at[2]. This proposal was followed by the adoption of UNGA resolution for environmental protection in war. Protection of the Environment in Times of Armed Conflict GA Res 47/37, A/Res/47/37 (1992).

${ }^{52}$ Koppe, above n 9, at 132; General and Complete Disarmament: Second Review Conference of the Parties to the Convention on the Prohibition of Military or Any Other Hostile Use of Environmental Modification Techniques GA Res 47/52(E), A/Res/47/52(E) (1992). 
to high technology, but also to low technology or conventional approaches. ${ }^{53}$

ENMOD prohibits environmental modification causing "widespread, long-lasting or severe" damage. Fortunately, clear definitions of these thresholds are expressly provided in the "Understandings". The term "widespread" may cover "an area on the scale of several hundred square kilometres"; "longlasting" includes "a period of months, or approximately a season"; and "severe" involves "serious or significant disruption or harm to human life, natural and economic resources or other assets". ${ }^{54}$ The clear definitions provided in this Convention arguably may contribute to the interpretation of similar terms in other treaties such as the 1977 Additional Protocol I (see below at [2.1.5]).

Note that the damage thresholds in ENMOD are expressed as alternatives, rather than cumulative requirements as in the 1977 Additional Protocol I below. This means that to establish a violation of ENMOD Convention, it is enough if only one of the thresholds is met, whereas to breach the $1977 \mathrm{Ad}$ ditional Protocol I the damage must meet all three and be widespread, longterm and severe.

Article I of ENMOD further states that the damage or injury must be directed "to any other state party". Thus the application of this Convention is limited to state parties, regardless of whether that state is a warring or a neutral party. This approach was taken in order to encourage states to ratify this Convention and to prevent states from gaining benefit from it without becoming parties to it. ${ }^{55}$ There remain, however, at least three kinds of damage which would fall outside the ambit of ENMOD: damage in the territory of a non-state party; ${ }^{56}$ damage in the territory of the acting state; and damage beyond the jurisdiction of states in areas such as the high seas (unless the ships of a state party to ENMOD were affected). ${ }^{57}$

5. The 1977 Protocol Additional to the Geneva Conventions of 12 August 1949 , and relating to the Protection of Victims of International Armed Conflicts ${ }^{58}$ (the 1977 Additional Protocol I)

Together with ENMOD, the 1977 Additional Protocol I ${ }^{59}$ provides provisions that specifically protect the environment during times of war. Articles $35(3)$ and 55 proffer significant legal protection to the environment by, for the first-time, expressly prohibiting the environment from being a specific military target. Unfortunately, as will be discussed, the Protocol is weakened by its failure to provide clear definitions of the relevant damage thresholds. Never-

\footnotetext{
${ }^{53}$ Tarasofsky, above n 17, at 47.

54 ENMOD Understandings, above $\mathrm{n} 46$, relating to art I.

${ }^{55}$ Roman Reyhani "Protection of the Environment during Armed Conflict" (2007) 14 MELPR 323 at 327.

${ }^{56}$ It has been noted that an environmental modification technique is not a violation of the ENMOD if employed by a state against its own people. Stephanie N. Simonds "Conventional Warfare and Environmental Protection: A Proposal for International Legal Reform” (1992) 29 Stan. J. Int’l L. 165 at 187.

${ }^{57}$ Dinstein, above n 2, at180.

58 The 1977 Additional Protocol I, above n 45.

${ }^{59}$ The Protocol is subscribed to by a remarkable number of states.As of 21 August 2012, it had 172 state parties including major states such as France, the People's Republic of China, the Russian Federation and the United Kingdom (UK). However, some important states have not become parties to this protocol such as the US, India, Israel, and Pakistan. See "Treaties and Documents by Date" (2012)International Committee of the Red Cross <www.icrc.org/ihl>.
} 
theless, these provisions should be considered as crucial because, in explicitly aiming to protect the environment during the war, theyprohibitenvironmental damagebased on a conception of the environment as inherently valuable in itself beyond solelyproviding for human benefit particularly art 35(3) below. ${ }^{60}$ Article 35(3) states:

[i]t is prohibited to employ methods or means of warfare which are intended, or may be expected, to cause widespread, long-term and severe damage to the natural environment.

Article 55 states:

1. [c]are shall be taken in warfare to protect the natural environment against widespread, long-term and severe damage. This protection includes a prohibition of the use of methods or means of warfare which are intended or may be expected to cause such damage to the natural environment and thereby to prejudice the health or survival of the population.

2. [a]ttacks against the natural environment by way of reprisals are prohibited.

While many commentators celebrate arts $35(3)$ and $55,{ }^{61}$ there is also a belief that these provisions are difficult to apply to real cases because of their vague wording and high thresholds for damage assessment. ${ }^{62}$

The 1977 Additional Protocol I does not provide clear guidance on the meaning of its damage thresholds: "widespread, long-term and severe". During the negotiation of the Protocol, only the "long-term" threshold was clarified as a period of at least ten years, ${ }^{63}$ while the other two thresholds were left undefined. ${ }^{64}$ The use of the conjunctive "and" in the phrase "widespread, long-term and severe" means that all three criteria must be met in order for

${ }^{60}$ Carolyn Stannard “Cases; Legal Protection of the Environment in Wartime” (1992) 14 Syd L. R. 373 at 375; Lawrence and Heller, above $\mathrm{n} 37$, at 66.

${ }^{61}$ Christopher D. Stone "The Environment in Wartime: An Overview" in Jay E. Austin and Carl E. Bruch (eds) The Environmental Consequences of War (Cambridge University Press, Cambridge, 2000) 16 at 21; Nada Al-DuaijEnvironmental Law of Armed Conflict (Transnational Publisher, New York, 2003) at 105; Schmitt, above n 22, at 70; Betsy Baker "Legal Protections for the Environment in Times of Armed Conflict" (1993) 33Va. J. Int'l L. 351 at 382; Alexandre Kiss "International Humanitarian Law and the Environment" (2001) 31(4-5) EnvtlPol'y\& L.223 at 225; Michael N. Schmitt "The Environmental Law of War: An Invitation to Critical Re-examination" (1996) 6 USAF Acad. J. Legal Stud. 237 at 257.

${ }^{62}$ Laurent R. Hourcle "Environmental Law of War" (2001) 25 Vt. L. Rev. 653 at 673; Michael Bothe, Karl Josef Partsch, and Waldemar A. SolfNew Rules for Victims of Armed Conflicts: Commentary on the Two 1977 Protocols Additional to the Geneva Conventions of 1949 (MartinusNijhoff Publishers, The Hague, 1987) at 348; Richard Desgagné "The Prevention of Environmental Damage in Time of Armed Conflict: Proportionality and Precautionary Measures"(2000) 3 YIHL109 at 113; Walter G. Sharp Sr. "The Effective Deterrence of Environmental Damage during Armed Conflict: A Case Analysis of the Persian Gulf War" (1992) 137 Mil. L. Rev. 1 at 16.

${ }^{63}$ Frits Kalshoven "Reaffirmation and Development of International Humanitarian Law Applicable in Armed Conflict: The Diplomatic Conference, Geneva, 1974-1977; Part II” (1978) 9 NYIL 107 at 130.

${ }^{64}$ One author commented that there was no authoritative answer to determine what kind of damage might fit into these thresholds.Another scholar also wrote that "the meaning of those terms is very controversial" and the thresholds are "unacceptably high". Furthermore, despite a number of proposals attempting to specifically define these terms, it has been noted that they remain open-ended definitions. Wil D. Verwey "Observations on the Legal Protection of the Environment in Times of International Armed Conflict" (1994) 7 Hague Y. B. Int'l L. 35 at 36; Michael Bothe "Protection of the Environment in Times of Armed Conflict" in Najeeb Al-Nauimi and Richard Meese (eds) International Legal Issues Arising under the United Nations Decade of International Law; Proceeding of the Qatar International Law Conference 1994 (MartinusNijhoff Publishers, The Hague, 1995) 95 at 100; Schwabach, above n 15, at 127. 
the Protocol to apply. This is said to be why Iraqi and coalition forces cannot be held liable for environmental damage caused during the 1991 Gulf War. ${ }^{65}$

Nevertheless, arts 35(3) and 55 signify a crucial development in the international law that protects the environment in times of hostilities. These provisions expressly protect the natural environment as an indispensable support to human health and survival. ${ }^{6}$ Such explicit protection for the environmentis likely to clarify the scope of application during hostilities, more effectively protecting the environment. Article 55 sets a lower standard but offers wider protection than art 35(3) by imposing a positive duty of care for the environment during warfare ${ }^{67}$ that involves states exercising due diligence by undertaking environmental impact assessments before launching military operations.$^{68}$ This obligation would be on-going and applicable both in offensive and defensive operations. ${ }^{69}$ Furthermore, arts 35(3) and 55 do not provide any exception or condition of military necessity similar to that under art 23(g) of the 1907 Hague Regulations. In reference to the vague wording of the thresholds, one expert has however suggested that this problem may be overcome by interpreting the thresholds similarly to those employed in ENMOD. ${ }^{70}$ Therefore, in addition to its express and specific prohibition against causing damage to the environment, arts 35(3) and 55 of the 1977 Additional Protocol I seem more reasonably applicable duringBesides arts 35(3) and 55, there are other provisions in the 1977 Additional Protocol I that may offer protection to the environment in indirect manner asthey are mainly intended to protect humans during war. These provisions are arts 51, 54(2), 56(1), 59 and 60.

Article 51 prohibits indiscriminate attacks including "those which employ a method or means of combat the effects of which cannot be limited as required by this Protocol". ${ }^{71}$ Further, art 51 considers an attack to be indiscriminate if it may be expected to cause "damage to civilian objects" that would be disproportionate to the actual and direct military advantage. ${ }^{72}$ This article may be used in connection with the environment because indiscriminate attacks may result in unnecessary damage and will eventually threaten the environment. Damage to civilian objects may include damage to properties such as houses, farmlands and buildings where all of these represent the elements of the environment.

Article 54(2) prohibits actions intended to "attack, destroy, remove

${ }^{65}$ Despite being acknowledged as widespread and severe, environmental damage inflicted by Iraq during the 1991 Gulf War has been doubted as reaching the level of "long-term", thus falling outside the application of Additional Protocol I. Al-Duaij, above n 61, at 106; Ines Peterson "The Natural Environment in Times of Armed Conflict: A Concern for International War Crimes Law?" (2009) 22 LJIL 325 at 342; Dinstein, above n 2, at194. See also Leslie C. Green "The Environment and the Law of Conventional Warfare" (1991) 29 Canadian YBIL 222 at 232; Peter J. Richards and Michael N. Schmitt "Mars Meets Mother Nature: Protecting the Environment during Armed Conflict" (1999) 28 Stetson L. Rev. 1047 at 1055-1061.

${ }^{66}$ Neil A.F. Popović "Humanitarian Law, Protection of the Environment, and Human Rights" (1995)

8Geo. Int'l Envtl L. Rev. 67 at 75; Al-Duaij, above n 61, at 105.

${ }^{67}$ Schmitt, above n 22, at 73-74.

${ }^{68}$ Koppe, above n 9, at 149.

69 Karen Hulme War Torn Environment: Interpreting the Legal Threshold (MartinusNijhoff, Leiden, 2004)at 80-88.

${ }^{70}$ Ibid, at 88-100.

${ }^{71}$ The 1977 Additional Protocol I, above n 45, art 51(4)(c).

72 Ibid, art 51(5)(b). 
or render useless objects indispensable to the survival of the civilian population". This provision expressly mentions "foodstuffs, agricultural areas for the production of foodstuffs, crops, livestock, drinking water installations and supplies and irrigation works" where these are in their natural form as part of the environment. ${ }^{73}$

Article 56(1) prohibits any attack on works or installations "containing dangerous forces, namely dams, dykes and nuclear electrical generating stations" even if they are legitimate military targets if "such attack may cause the release of dangerous forces and consequent severe losses among the civilian population". ${ }^{74}$ Other military targets located at or in the vicinity of these sites are entitled to the same protection. ${ }^{75}$ The protection afforded by art $56(1)$ ceases to apply if the works are used "in regular, significant and direct support of military operations and if such attack is the only feasible way to terminate such support". ${ }^{76}$

Finally, arts 59 and 60 enable environmental protection by allowing states to create special protection zones. ${ }^{77}$ Non-defended localities ${ }^{78}$ under art 59 are absolutely protected from attack and can be declared unilaterally, or by agreement of the warring parties. Article 60 prohibits military actions in agreed "demilitarised zones". ${ }^{79}$ Demilitarised zones between North Korea and South Korea, created under art 60, have been proven to provide sanctuary to endangered and threatened animals and plants. ${ }^{80}$

\section{The 1981 Certain Conventional Weapons Convention and its Protocol III}

Another treaty that specifically protects the environment during armed conflict is the 1981 Convention on Prohibitions or Restrictions on the Use of Certain Conventional Weapons Which May Be Deemed to be Excessively Injurious or to Have Indiscriminate Effects ${ }^{81}$ and especially its third Protocol on Prohibitions or Restrictions on the Use of Incendiary Weapons (Protocol III). ${ }^{82}$ As of 21August 2012, 115 and 108 state parties have ratified this Convention and the Protocol respectively. ${ }^{83}$

The 1981 Convention's first reference to the environment is located in its preamble, by recalling the prohibition on employing "methods or means of warfare which are intended, or may be expected, to cause widespread, long-

${ }^{73}$ Ibid, art $54(2)$.
${ }^{74}$ Ibid, art $56(1)$.
${ }^{75}$ Ibid.
${ }^{76}$ Ibid, art $56(2)$.
${ }^{77}$ Tarasofsky, above n 17 , at 53.
${ }^{78}$ The 1977 Additional Protocol I, above n 45, art 59.
${ }^{79}$ Ibid, art 60.
${ }^{80}$ SeeKe Chung Kim “Preserving Biodiversity in Korea's Demilitarised Zone" (1997) 278(5336) Science 242 .

${ }^{81}$ Convention on Prohibitions or Restrictions on the Use of Certain Conventional Weapons Which May Be Deemed to Be Excessively Injurious or to Have Indiscriminate Effects (opened for signature 10 April 1981, entered into force 2 December 1983) [Certain Conventional Weapons Convention].

82 Protocol on Prohibition or Restrictions on the Use of Incendiary Weapons (Protocol III) to the Convention on Prohibitions or Restrictions on the Use of Certain Conventional Weapons Which May Be Deemed to Be Excessively Injurious or to Have Indiscriminate Effects (opened for signature 10 April 1981, entered into force 2 December 1983) [Protocol III of the Certain Conventional Weapons Convention].

83 "Treaties and Documents by Date" (2012)International Committee of the Red Cross <www.icrc. org/ihl>. 
term and severe damage to the natural environment". ${ }^{84}$

Although clearly not one of the Convention's actual rights or duties, this reference may have legal importance. ${ }^{85}$ According to art 31 of the Vienna Convention on the Law of Treaties, a preamble may play an important role in the interpretation of a treaty. ${ }^{86}$ In addition, a convention's preamble commonly represents the motives of states parties and the underlying principles of the convention itself. ${ }^{87}$

The wording of the preamble to the 1981 Convention seems deliberately similar to art 35(3) of the 1977 Additional Protocol I. The decision to employ this wording by the drafter reflects the emergence of a customary law regarding the principle of environmental protection. ${ }^{88}$ Unfortunately, the inclusion of this statement in the preamble has led to two major states, France and the US, attaching a reservation and a declaration respectively to the Convention on ratification. These clauses state that the preamble's first paragraph only binds those states that have subscribed to the 1977 Additional Protocol I. ${ }^{89}$ Such a position is likely based on the fact that some major states persistently claim that arts 35(3) and 55(1) of the 1977 Additional Protocol I are not customary. ${ }^{90}$

The 1981 Convention's second important reference to the environment appears in art 2(4) of the Convention's Protocol III. It prohibits states from making "forests or other kinds of plant cover the object of attack by incendiary weapons except when such natural elements are used to cover, conceal or camouflage combatants or other military objectives, or are themselves military objectives". 91

Given their references to environmental protection, these treaties offer clear and significant legal protection since armed conflicts that have occurred

\footnotetext{
${ }^{84}$ Certain Conventional Weapons Convention, above $\mathrm{n}$ 81, Preamble.

${ }^{85}$ Koppe, above n 9, at 187.

${ }^{86}$ Vienna Convention on the Law of Treaties(opened for signature 23 May 1969, entered into force 27 January 1980), arts 31(1) and (2).

${ }^{87}$ Gerald Fitzmaurice "The Law and Procedure of the International Court of Justice 1951-4: Treaty Interpretation and Other Treaty Points" (1957) 33 BYIL 203 at 228; Ian Sinclair The Vienna Convention on the Law of Treaties (Manchester University Press, Manchester, 1984) at 127.

${ }^{88}$ Koppe, above n 9, at 187.

89 France's reservation provides that "France, which is not bound by Additional Protocol I of 10 June 1977 to the Geneva Conventions of 12 August 1949, considers that the fourth paragraph of the preamble to the Convention on Prohibitions or Restrictions on the Use of Certain Conventional Weapons Which May Be Deemed to Be Excessively Injurious or to Have Indiscriminate Effects, which reproduces the provisions of art 35, paragraph 3, of Additional Protocol I, applies only to States parties to that Protocol". "France's Reservation to the Convention on Prohibitions or Restrictions on the Use of Certain Conventional Weapons Which May Be Deemed to Be Excessively Injurious or to Have Indiscriminate Effects" (2012) International Committee of the Red Cross <www.icrc.org/ihl $>$. The US considered "that the fourth paragraph of the preamble to the Convention, which refers to the substance of provisions of article 35(3) and article 55(1) of additional Protocol I to the Geneva Conventions for the Protection of War Victims of August 12, 1949, applies only to States which have accepted those provisions". "The US' Declaration to the Convention on Prohibitions or Restrictions on the Use of Certain Conventional Weapons Which May Be Deemed to Be Excessively Injurious or to Have Indiscriminate Effects" (2012) International Committee of the Red Cross <www.icrc.org/ihl>.Schmitt, above n 22, at 88-89; Michael N. Schmitt "Humanitarian Law and the Environment" (2000) 28 Denv.J. Int'l L. \&Pol'y 265 at 287-288; Koppe, above n 9, at 186.

90 This was submitted by the UK and the US to the International Court of Justice in the Nuclear Weapons case. Jean-Marie Henckaerts and Louise Doswald-Beck Customary International Humanitarian Law. Volume I: Rules (Cambridge University Press, Cambridge, 2005) at 153.

${ }_{91}$ Protocol III of the Certain Conventional Weapons Convention, above n 82, art 2(4).
} 
up until today have involved mainly weapons that fall within their scope - in particular, incendiary weapons. ${ }^{92}$

\section{The 1998 Statute of the International Criminal Court}

The most recent treaty adopted by states providing for the protection of the environment during times of war is the Statute of the International Criminal Court (ICC Statute). ${ }^{93}$ This treaty established a permanent international criminal court with the main objective of prosecuting war criminals (individual military members or political leaders) for ordering or committing certain war crimes. The Court is therefore not concerned with state responsibility but is rather focused on individual criminal responsibility. Nevertheless, it counts crimes against the environment as war crimes and, in so doing, sends a strong message to military leaders to consider the environment during times of war or face criminal prosecution. ${ }^{94}$

Article 8(2)(b)(iv) of the ICC Statute criminalises as a war crime: ${ }^{95}$

[i]ntentionally launching an attack in the knowledge that such attack will cause (...) widespread, long-term and severe damage to the natural environment which would be clearly excessive in relation to the concrete and direct overall military advantage anticipated.

This wording mirrors that of arts 35(3) and 55 of the 1977 Additional Protocol I. Unfortunately, the three terms "widespread, long-term and severe" are also undefined in the ICC Statute. Nevertheless, art 8(2)(b)(iv) may be considered as a step forward in criminalising negative actions against the environment at the international level. This is because pre-existing laws were discretionary, ${ }^{96}$ only encouraging states to criminalise environmental destruction actions under their national legal system and to require extradition or prosecution of individual perpetrators in cases of grave breaches. ${ }^{97}$

Neither does it appear that art 8(2)(b)(iv) requires actual damage to the environment or direct harm to take place. According to authoritative com-

${ }^{92}$ Incendiary weapons are "designed to inflict damage on the enemy, his positions, or his environment primarily through the action of heat and flame. Besides these incendiary effects some incendiary agents are poisonous and some produce toxic or asphyxiating effects when burning. Incendiary weapons may be used as air weapons in the form of fire-bombs, in the form of grenades, small rockets, mortar ammunition and artillery projectiles. Other types of ground incendiary weapons include flamethrowers and emplaced devices such as landmines and flame fougasses. The main categories of agents used are oilbased incendiaries (napalm), metal incendiaries (magnesium), pyrotechnical incendiaries (thermite) and pyrophoric incendiaries (white phosphorus)". PerttiJoenniemi "Conventional Weapons: A Revived Issue" (1976) 6 Instant Research on Peace and Violence 29 at 30.

${ }^{93}$ Statute of the International Criminal Court (opened for signature 17 July 1998, entered into force 1 July 2002) [ICC Statute].

94 The history of criminal liability for environmental damage during wartime is illustrated by the prosecution case against German General LotharRendulic, who was accused of wanton property destruction after ordering the evacuation of all the inhabitants of Finmark province, Norway and destroying all villages and their surrounding infrastructures. Trial of Wilhelm List and Others (The Hostages Trial); Case No. 47 in The United Nations War Crimes Commission Law Reports of Trials of Major War Criminals, Vol. VIII (His Majesty's Stationary Office, London, 1949) [the Hostages trial] 34 at 68.

${ }_{95}$ ICC Statute, above $\mathrm{n} 93$, art 8(2)(b)(iv).

${ }^{96}$ Lawrence and Heller, above $n$ 37, at 69-70.

97 Article 146 of the Geneva IV Convention requires state parties to pass domestic legislation in order to prosecute those who commit or order action amounting to such proscribed actions and to prosecute such offenders before their courts regardless of their nationality. Fourth Geneva Convention, above n 33 , art 146. 
mentary on the ICC Statute, the mere action of launching a potentially devastating attack would bring this provision into play. ${ }^{98}$ Article 8(2)(b)(iv) has even been considered - perhaps somewhat ambitiously - to be "eco-centric" because there is no need to establish that direct harm to humans has occurred in order to trigger this provision. ${ }^{99}$

Besides specific protection of the environment under art 8(2)(b)(iv), there are other provisions of the ICC Statute that address environmental harm, albeit incidentally. ${ }^{100}$ These provisions protect the environment as a support for human life and not purely because of the intrinsic value of the environment itself. ${ }^{101}$ Despite this, the end effect of these provisions is undeniably protecting the environment which makes it important for them to be identified.They are: art 8(2)(a)(iv) (prohibiting extensive destruction and appropriation of property not justified by military necessity and carried out wantonly and unlawfully); art 8(2)(b)(ii) (prohibiting the intentional directing of attacks against civilian objects which are not military objectives);art $8(2)$ (b) (xvii) (prohibiting the use of poison and poisoned weapons); and art 8(2)(b)(xviii) (prohibiting the employment of asphyxiating, poisonous, or other gases).

\section{B.Customary Law}

In addition to treaty rules, the environment is also protected during times of war by customary international laws of war. ${ }^{102}$ Recognition of customary law within IHL is crucial because of the possibility that belligerent states are not party to relevant treaty laws. Customary law normally binds all states that have not persistently objected to its development ${ }^{103}$ and violation of the rules ofcustomary law is recognised as having legal consequences for the states responsible. ${ }^{104}$ Thus, both sides of an armed conflictwill be bound by customary law, without exception.

This section tries to identifyrelevant customary rules and discusses how they may offer protection to the environment during wartime based on current state practice and literature. ${ }^{105}$ For the purpose of clarity, the exami-

98 Knut DörmannElements of War Crimes under the Rome Statute of the International Criminal Court; Sources and Commentary (Cambridge University Press, Cambridge, 2004) at 162.

${ }^{99}$ Lawrence and Heller, above n 37, at 71.

100 Mark A. Drumbl “Waging War against the World: the Need to Move from War Crimes to Environmental Crimes"in Jay E. Austin and Carl E. Bruch (eds) The Environmental Consequences of War (Cambridge University Press, Cambridge, 2000) 620 at 632-633.

101 Mark A. Drumbl "Accountability for Property Crimes and Environmental War Crimes: Prosecution, Litigation, and Development" (2009)Research Project of International Center for Transitional Justice $<$ www.ictj.org/publications> at 7-10.

${ }^{102}$ Tarasofsky, above n 17, at 22; Koppe, above n 9, at 204.As Schmitt observes: "Custom is at the core of the ius in bello. Indeed, as a source of the law of war it predates any of the applicable treaty law currently in force", above n 22, at 51.

${ }^{103}$ Cassese, above $\mathrm{n} 7$, at 157.

104 According to the International Law Commission (ILC), a breach of an international obligation is "when the act in question is not in conformity with what is required by that obligation 'regardless of its origin'. (...) They apply to all international obligations of states, whatever their origin may be. International obligations may be established by a customary rule of international law, by a treaty or by a general principle applicable within the international legal order". Commentary to draft art 12, paragraph 3, Draft Articles on Responsibility of States for Internationally Wrongful Acts and Commentaries.Report of the International Law Commission to the General Assembly on the Work of its Fifty-third session A/56/10 (2001) at [126].

105 In order to attain customary status, a rule must first be amount to general practice, which 
nation of these rules may be divided into two categories: first,environmental protection under general customary rules within the principles of the law of war; and second, provisions from treaties in the law of war considered above, which have attained the status of customary law. ${ }^{106}$

\section{General Customary Principles of IHL (Law of War)}

Environmental protection from the customary principles of the law of war occursindirectly (if at all) via protection of people and property. There is no recognised text that defines all the customary principles of law of war. ${ }^{107}$ However, two central foundations of the law of warare undisputed. These are: first, that the only legitimate object that states may endeavour to accomplish during war is to weaken the military forces of the enemy; and second, thatthe choice of means and methods of warfare by belligerents is not unlimited. ${ }^{108}$ Following on from these two propositions are four principles which become the parameters of permissible actions during hostilities by belligerents. They are the principles of necessity, humanity, proportionality and discrimination ${ }^{109}$ and each of these principles: ${ }^{110}$ strongly points to the conclusion that actions resulting in massive environmental destruction, especially where they do not serve a clear and important military purpose, would be questionable on many grounds, even in the absence of specific rules of war addressing environmental matters in detail. When the four principles are taken together, such a conclusion would seem inescapable.

The principle of neutrality may also protect the environment of neutral parties from potential cross-border damage during armed conflicts.

is usually a self-evident situation, and states must regard this general practice as a legal obligation. If a state violates such customary rule, there will be legal consequences for violation of this rule. The first requirement is commonly considered as an objective or material condition while the second requirement is considered to be a subjective or psychological condition or opinioniurissivenecessitatis. Anthony AustHandbook of International Law (2nd ed, Cambridge University Press, Cambridge, 2010) at 6-8; North Sea Continental Shelf (Federal Republic of Germany v Denmark / the Netherlands) (Merit) [1969] ICJ Rep 3 at 44; G. I. Tunkin "Remarks on the Juridical Nature of Customary Norms of International Law" (1961) 49 CLR 419 at 423; Rein Müllerson "The Interplay of Objective and Subjective Elements in Customary Law" in KarelWellens (ed) International law: Theory and Practice: Essays in Honour of Eric Suy(MartinusNijhoff Publishers, The Hague, 1998) 161 at 161.

${ }^{106}$ Koppe, above n 9, at 214-268.

${ }^{107}$ Richard Falk "The Environmental Law of War: An Introduction" in Glen Plant (ed) Environmental Protection and the Law of War; A "Fifth Geneva" Convention on the Protection of the Environment in Time of Armed Conflict (Belhaven Press, New York, 1992) 78 at 84.

${ }^{108}$ The former foundation was incorporated in the 1868 St. Petersburg Declaration while the latter was incorporated in the 1874 Brussels Declaration and the 1880 Oxford Manual and was formally codified in the 1899 and 1907 Hague Regulations, in art 35(1) of the 1977 Additional Protocol I, and in the preambles of the 1980 Convention on Certain Conventional Weapons and the 1997 Ottawa Convention on Anti-Personnel Mines. Tarasofsky, above n 17, at 22; Adam Roberts and Richard Guelff (eds) Documents on the Laws of War (3rd ed, Oxford University Press, Oxford, 2000) at 9.

109 United Nations of Environmental Programme Protecting the Environment during Armed Conflict: An Inventory and Analysis of International Law (United Nations of Environmental Programme, Nairobi, 2009) at 12. [UNEP 2009]; Falk, above n 107, at 84; Caggiano, above n 16, at 494; Simonds, above $n$ 56 , at 168.

110 Adam Roberts "Environmental Issues in International Armed Conflict: The Experience of the 1991 Gulf War"in Richard J. Grunawalt, John E. King, and Ronald S. McClain (eds) Protection of the Environment during Armed Conflict (Naval War College, Rhode Island, 1996) 222 at 228. Further, Simonds has argued that " $[t]$ hese guidelines outlaw wanton environmental damage by prohibiting widespread destruction disproportionate to an anticipated military goal”, above n 56, at 169-170. 


\subsubsection{Principle of (Military) Necessity}

The principle of necessity determines that an action in warfare is lawful if the weapons and tactics employed are reasonably necessary to achieve military objectives. ${ }^{111}$ This principle is found in the 1863 Lieber Code, ${ }^{112}$ the $1868 \mathrm{St}$ Petersburg Declaration ${ }^{113}$ and the International Military TribunalCharter. ${ }^{114}$ It is also foundin art 23(g) of the 1907 Hague Regulations concerning protection of enemy property. This outlaws action intended "to destroy or seize the enemy's property, unless such destruction or seizure be imperatively demanded by the necessities of war". ${ }^{115}$ As discussed previously, "property" mayinclude the environment so it offers protection, albeit indirect. ${ }^{116}$ Furthermore, this rule was employed during the Nuremberg Tribunals to charge certain German Generals with destruction of enemy property. ${ }^{117}$

\subsubsection{Principle of Discrimination}

Under the principle of discrimination, ${ }^{118}$ belligerents are requiredat all times to distinguish between "civilian objects and military objectives and accordingly [to] direct their operations only against military objectives". ${ }^{119}$ Article 52(2) of the 1977 Additional Protocol I defines military objectives as those that "by nature, location, purpose or use make an effective contribution to military action and whose total or partial destruction, capture or neutralisation, in the circumstances ruling at the time, offers a definite military advantage". ${ }^{120}$ Thus,

${ }^{111}$ Falk, above n 107, at 84; Roberts, ibid, at 228; Tarasofsky, above n 17, at 23.

112 Article 14 states: "[m]ilitary necessity, as understood by modern civilised nations, consists in the necessity of those measures which are indispensable for securing the ends of the war, and which are lawful according to the modern law and usages of war". "Instructions for the Government of Armies of the United States in the Field (1863 Lieber Code)" in Leon Friedman (ed) The Law of War - A Documentary History (Random House, New York, 1972) at 158.

${ }^{113}$ It limits states' usage of special weapons in warfare that cause unnecessary injury to the enemy where it is considered to be the violation of the law of humanity. The Declaration of St. Petersburg Renouncing the Use, in Time of War, of Explosive Projectiles under 400 Grammes Weight (signed and entered into force 11 December 1868).

${ }^{114}$ Article 6(b) of the Charter specifically characterises "wanton destruction of cities, towns or villages, or devastation not justified by military necessity" as a war crime. Charter of the International Military Tribunal (signed 8 August 1945, entered into force 8 August 1945).

115 The 1907 Hague Regulations, above n 11, art 23(g) (emphasis added).

116 See fn14 above.

117 The Hostages trial, above n 94, at 66-68; The Tribunal stated that: "[t]o claim that [rules and customs of warfare] can be wantonly - and at the sole discretion of any one belligerent - disregarded when he considers his own situation to be critical, means nothing more or less than to abrogate the laws and customs of war entirely". "Trial of Alfried Felix Alwyn Krupp Von Bohlen Und Halbach and Eleven Others (Krupp Trial); Case No. 58" in The United Nations War Crimes Commission Law Reports of Trials of Major War Criminals, Vol. X (His Majesty's Stationary Office, London, 1949) 34 at 139; "Trial of von Leeb and Thirteen Others (German High Command Trial); Case No. 72" in The United Nations War Crimes Commission Law Reports of Trials of Major War Criminals, Vol. XII (His Majesty's Stationary Office, London, 1949) 1 at 93-94.

118 With reference to the environment, this principle is affirmed in some provisions of legal instruments and endorsed by an international document such as arts 35(3), 48, 51 and 57 of the 1977 Additional Protocol I, art 2(4) of the Protocol III of the Certain Conventional Weapons Convention, and the 1994 Guidelines for Military Manuals and Instructions on the Protection of the Environment in times of Armed Conflict.

119 The 1977 Additional Protocol I, above n 45, art 48.

120 Ibid, art 55(2). 
the environment may receive protection during times of war through the distinction of military objectives from civilian objects. ${ }^{121}$ For example, military attacks on environmentally important areas such as national parks and productive forest would be contrary to this principle and, subsequently, to art $52(2) \cdot{ }^{122}$

\subsubsection{Principle of Humanity}

The principle of humanity requires that any weapons and tactics employed in warfare not cause superfluous suffering to victims by way of "prolonged or painful death" orby being in a "form calculated to cause severe fright or terror". ${ }^{123}$ Weapons and tactics, which might result in these outcomes, are illegal per se. For example, the poisoning of water supplies and the destruction of agricultural land and timber resources that are vital to the population could be considered "inhumane" means of warfare. ${ }^{124}$ In other words, these acts are intuitively recognised as inherently wrongful or violate the "dictate of public conscience". ${ }^{125}$

In IHL, the requirement to conform to the "dictate of public conscience" is derived from the so-called "Martens Clause" ${ }^{126}$ which also refers to the "laws of humanity". ${ }^{127}$ This clause aimed to anticipate and prevent a pessimistic interpretation of the law of war arising, providing that anything not expressly prohibited was permitted. It has two fundamental functions: "to preserve the existing body of customary law not yet codified and to allow for its continuous development". ${ }^{128}$

In terms of environmental protection, increased global environmental awareness means that a state's actions during times of war will be assessed in the court of public conscience. ${ }^{129}$ Many scholars support the idea that environmental protection or consideration is included within the principles referred to in the Martens Clause. ${ }^{130}$ Further, some have observed that "international

\footnotetext{
${ }^{121}$ Henckaerts and Doswald-Beck, above n 90, at 143.

122 UNEP 2009, above n 109, at 13.

${ }^{123}$ Falk, above $\mathrm{n} 107$, at 84-85.

${ }^{124}$ UNEP 2009, above n 109, at 13.

125 Schmitt, above n 22, at 61 .
}

${ }^{126}$ It was originally stipulated in the Preamble to the 1899 Hague Convention II that reads: “[u] ntil a more complete code of the laws of war is issued, the High Contracting Parties think it right to declare that in cases not included in the Regulations adopted by them, populations and belligerents remain under the protection and empire of the principles of international law, as they result from the usages established between civilised nations, from the laws of humanity and the requirements of the public conscience". The 1899 Hague Convention (II) with respect to the Laws and Customs of War on Land, with annexed Regulations (opened for signature 29 July 1899, entered into force 4 September 1900), preamble. It was then repeated in several instruments such as the Preamble of Hague Convention (IV) of 1907; arts 63, 62, 142, and 158 respectively of the four Geneva Conventions of 1949; art 1(2) of the 1977 Additional Protocol I; and in the Preamble of the 1977 Additional Protocol II. See Theodor Meron "The Martens Clause, Principles of Humanity, and Dictates of Public Conscience" (2000) 94 AJIL 78.

${ }^{127}$ Koppe, above $\mathrm{n}$, at 115.

${ }^{128}$ Tarasofsky, above $\mathrm{n} 17$, at 33-35.

129 It is interesting to note what Canada has claimed in regard to environmental protection rules during armed conflict. The Canadian government stated that: " $[t]$ he customary laws of war, in reflecting the dictates of public conscience, now include a requirement to avoid unnecessary damage to the environment. This includes consideration of environmental effects in the planning of military operations". Barry Mawhinney "Canadian Practice in International Law; At the Department of External Affairs in 1991-1992" (1992) 30 Canadian YBIL347 at 347.

${ }^{130}$ Philippe Sands Principles of International Environmental Law (2nd ed, Cambridge University 
concern for the environment expressed through international environmental law has resulted in environmental protection becoming a factor which the military must take into account in determining the means and methods of warfare" ${ }^{131}$ Finally, the International Union for the Conservation of Nature (IUCN) recommended the adoption of a "Martens Clause for Environmental Protection" at the Second World Conservation Congress in Amman in 2000. ${ }^{132}$

\subsubsection{Principle of Proportionality}

The requirement under the principle of proportionality is that "incidental damage affecting the natural environment must not be excessive in relation to the military advantage anticipated from an attack on military objective". ${ }^{133}$ This principle is usually discussed along with the principle of military necessity ${ }^{134}$ because the former is frequently considered as the component in assessing the latter principle. ${ }^{135}$ Actions such the destruction of an entire village or burning of an entire forest to pursue minor targets; or the massive pollution resulted from the burning and spilling oil during the 1991 Gulf War are widely considered as disproportionate. ${ }^{136}$

States and international courts have recognised the principle of proportionality in environmental protection. ${ }^{137}$ During its bombing campaign in Yugoslavia in 1999, the North Atlantic Treaty Organisation (NATO) ${ }^{138}$ recognised

Press, Cambridge, 2003) at 311; SiljaVöneky “Peacetime Environmental Law as a Basis of State Responsibility for Environmental Damage Caused by War" in Jay E. Austin and Carl E. Bruch (eds) The Environmental Consequences of War (Cambridge University Press, Cambridge, 2000) 190 at 218; Bothe, Partsch, and Solf, above $n$ 63, at 56. Indeed, this was one conclusion of the 1991 Ottawa Conference of Experts on 'the Use of the Environment as a Tool of Conventional Warfare' where: "there was a shared view that the application and development of the law of armed conflict have to take into account the evolution of environmental concerns generally. The customary laws of war, in reflecting the dictates of public conscience, now include a requirement to avoid unnecessary damage to the environment". Chairman's Conclusions, 1991 Ottawa Conference on the Use of the Environment as a Tool of Conventional Warfare, paragraph 9. Quoted in Tarasofsky, above $\mathrm{n} 17$, at 35 .

${ }^{131}$ Low and Hodgkinson, above n 15, at 445.

132 The recommendation provides that: "[u]ntil a more complete international code of environmental protection has been adopted, in cases not covered by international agreements and regulations, the biosphere and all its constituent elements and processes remain under the protection and authority of the principles of international law derived from established custom, from dictates of the public conscience, and from the principles and fundamental values of humanity acting as steward for present and future generations". IUCN "Second World Conservation Congress: Resolutions and Recommendations" [Recommendation 2.97] IUCN (2000) <www.iucn.org >.

${ }^{133}$ Henckaerts and Doswald-Beck, above n 90, at 145.

134 Ling-Yee Huang "The 2006 Israeli-Lebanese Conflict: A Case Study for Protection of the Environment in Times of Armed Conflict"(2008) 20 Fla. J. Int'l L. 103 at 107. The principle of proportionality is clearly stated in the Additional Protocol I by obliging states to "refrain from deciding to launch any attack which may be expected to cause incidental loss of civilian life, injury to civilians, damage to civilian objects, or a combination thereof, which would be excessive in relation to the concrete and direct military advantage anticipated".The 1977 Additional Protocol I, above n 45, art 57(2)(iii).

${ }^{135}$ Schmitt, above $\mathrm{n} 22$, at 55.

${ }^{136}$ UNEP 2009, above n 109, at 13.

137 This recognition may be found also in the UN Guidelines for Military Manuals and Instructions on the Protection of the Environment in times of Armed Conflict. Report of the Secretary General:United Nations Decade of International Law A/49/323 (1994) at [annex, 4].

138 The North Atlantic Treaty Organization or NATO is an intergovernmental military alliance based on the North Atlantic Treaty, which was signed on 4 April 1949, and it constitutes a collective defence system of mutual defence in response to any attack by external party. In 1999, NATO's members were Belgium, Canada, the Czech Republic, Denmark, France, Germany, Greece, Hungary, Iceland, Italy, Luxemburg, 
this principle in its decisions determining targets by taking into account "all possible 'collateral damage', be it environmental, human, or to civilian infrastructure". ${ }^{139}$ In examining the damage caused by NATO's subsequent bombing, the Committee Established to Review the NATO Bombing Campaign against the formerFederal Republic of Yugoslavia (FRY) stated that the impacts were "best considered from the underlying principles of the law of armed conflict such as necessity and proportionality". ${ }^{140}$ Finally, the International Court of Justice (ICJ) hasconfirmed in its Advisory Opinion on Nuclear Weapons that: ${ }^{141}$

[s] tates must take environmental considerations into account when assessing what is necessary and proportionate in the pursuit of legitimate military objectives. Respect for the environment is one of the elements that go to assessing whether an action is in conformity with the principles of necessity and proportionality.

\subsubsection{Principle of Neutrality}

According to the principle of neutrality, the environment of neutral and non-participating countries should be protected during armed conflicts. ${ }^{142}$ This applies to trans-boundary and environmental damage. ${ }^{143}$ From this basic rule, rights and duties of neutral states have developed into the law of neutrality as part of ius in bello or the law of war. The law of neutrality was codified in the 1907 Hague Convention V in the Case of War on Land ${ }^{144}$ and the Hague Convention XIII in the Case of Naval War. ${ }^{145}$

In an armed conflict, a state is considered to be neutral if it declares its neutrality and acts in a neutral manner towards all belligerents. ${ }^{146}$ This declaration and action of neutrality will protect the population and environment of the neutral state against any attack by the belligerents. ${ }^{147}$ Violations will be

\footnotetext{
the Netherlands, Norway, Poland, Portugal, Spain, Turkey, the United Kingdom and the United States. North Atlantic Treaty Organization "NATO's Open Door Policy" (2012) NATO<www.nato.int>.

${ }^{139}$ VojinJoksimovich "Militarism and Ecology: NATO Ecocide in Serbia" (2000) 11(4) Mediterranean Quarterly 140 at 142.

140 "Final Report to the Prosecutor by the Committee Established to Review the NATO Bombing Campaign against the Federal Republic of Yugoslavia" (2000) International Criminal Tribunal for the Former Yugoslavia (ICTY) <www.icty.org> at 15.It addressed the principle at [22], stating that: "[i]n order to satisfy the requirement of proportionality, attacks against military targets which are known or can reasonably be assumed to cause grave environmental harm may need to confer a very substantial military advantage in order to be considered legitimate".

${ }^{141}$ Legality of the Threat or Use of Nuclear Weapons(Advisory Opinion) [1996] ICJ Rep 226 [Nuclear Weapon Advisory Opinion] at 241-242.

${ }^{142}$ Al-Duaij, above n 61, at 108.

${ }^{143}$ Glen Plant "Environmental Damage and the Laws of War: Points Addressed to Military Lawyers" in Hazel Fox and Michael A. Meyer (eds) Effecting Compliance (British Institute of International and Comparative Law, London, 1993) 159 at 164.

${ }^{144}$ It provides that "the territory of neutral powers is inviolable". The 1907 Hague Convention (V) Respecting the Rights and Duties of Neutral Powers in Case of War on Land (opened for signature 18 October 1907, entered into force on 26 January 1910), art 1.

145 The 1907 Hague Convention (XIII) Concerning the Rights and Duties of Neutral Powers in Naval War (opened for signature 18 October 1907, entered into force on 26 January 1910).

146 Falk, above n 107, at 85.

${ }^{147}$ Adam Roberts "Failures in Protecting the Environment in the 1990-91 Gulf War"in Peter Rowe (ed) The Gulf War 1990-91 in International and English Law (Routledge, London, 1993) 111 at 118; Koppe, above $\mathrm{n} 9$, at 300 .
} 
regarded as acts of aggression giving rise to international responsibility. ${ }^{148} \mathrm{As}$ an example following World War II, Switzerland, a neutral state, successfully sought compensation from the Allied Nations for collateral damage to its territory caused by their attacks on neighbouring areas of Germany. ${ }^{149}$

The environmental protection afforded by this principle is favourable because the principle is enforced by non-belligerents correcting violationsof their sovereignty, including their environment. Under the law of neutrality, anytreaty relationships existingbetween belligerents and neutral states remain applicable during hostilities. ${ }^{150}$ Thus, belligerents must continueto perform all their treaty obligations, particularly towards neutral states. ${ }^{151}$ In addition, declaration or action of neutrality will protect the population and environment of the neutral state against any attack from the belligerents. This inviolability includes trans-boundary damage and, in particular, environmental damage. Violations of this protection will be regarded as an act of aggression and entail international responsibility. ${ }^{152}$

\section{Customary Status of Treaty Provisions}

As stated above, there exist some obligations which stem from treaty law but have also attained customary status that may protect the environment during times of war. These obligations may arise under treaty provisions that are declaratory of pre-existing norms of customary international law, or such provisions may have developed into customary international law. ${ }^{153}$ Either way, they bind belligerent states that do not subscribe to the particular treaty in question.

For example, the environmental protection provisions from the 1907 Hague Regulations, the 1925 Geneva Gas Protocol, the1949 Geneva IV Convention, and ENMOD ${ }^{154}$ have been acknowledged as part of customary international law that potentially bind all states as examined below.

The International Military Tribunal and the ICJ ${ }^{155}$ have both recognisedthe customary status of Article 23(g) of the 1907 Hague IV Convention, the former stating that: ${ }^{156}$

[t]he Hague Regulations prohibited "the destruction or seizure of enemy property except in cases where this destruction or seizure is urgently required by the necessities of war". Article 23(g). The Hague Regulations are mandatory provisions of International Law.

The provisions of the 1925 Gas Protocol may have attained custom-

\footnotetext{
${ }^{148}$ Al-Duaij, above n 61, at 108.

149 Michael Bothe "The Protection of the Environment in Times of Armed Conflict; Legal Rules, Uncertainty, Deficiencies, and Possible Developments"(1991) 34 GYIL 54 at 59-60.

${ }^{150}$ Simonds, above n 56, at 188; Koppe, above n 9, at 269.Tarasofsky argues that, to the extent that the laws of neutrality permit, a state of peace exists between neutral and belligerents. Tarasofsky, above $\mathrm{n}$ 17 , at 32 .

${ }^{151}$ Glen Plant "Legal Aspects of Marine Pollution during the Gulf War" (1992) 7 Int'l J. Estuarine and Coastal L. 217 at 219.

${ }^{152}$ Roberts, above n 147 at 118; Plant, above n 143, at 164; Al-Duaij, above n 61, 108.

${ }^{153}$ Koppe, above $n$ 9, at 214 .

${ }^{154}$ Discussed above from [2.1].

${ }^{155}$ Nuclear Weapons Advisory Opinion, above n 141, at 256; Legal Consequences of the Construction of a Wall in the Occupied Palestinian Territory, (Advisory Opinion) [2004] ICJ Rep 136 at 172.

156 The Hostages trial, above n 94, at 69 (emphasis added).
} 
ary statusbecause they have been "relatively well observed"157and the use of poison gas is frequently judged as a violation of international law. ${ }^{158}$ Furthermore, the Protocol's prohibitions are now accepted as general rules of international law that impose duties upon all states. ${ }^{159}$ UNGA resolutions have recognised that the 1925 Protocol "embodies the generally recognised rules of international law prohibiting the use in international armed conflicts of all biological and chemical methods of warfare, regardless of any technical developments" 160 and have reaffirmed "the necessity of strict observance by all states of the principles and objectives of

Rules from the 1949 Geneva Convention IV that protect the environment have generally been recognised as customary international law. ${ }^{161} 194$ states -virtually all states in the world -are parties to the 1949 Geneva Conventions. ${ }^{162}$ This level of acceptance even outstripsstate acceptance of the UN Charter with 193states. ${ }^{163}$ Thus provisions in the Geneva Conventions, including those which protect the environment, have attained the status of customary international law. ${ }^{164}$ Moreover, the ICJ has confirmed the customary status of these Conventions. ${ }^{165}$

Drafters of ENMOD deemed it to be made up of continuing innovative rules. If true, this would limit the Convention's application to state parties only. Someof today's scholars, however, argue that ENMOD may become customary international law as reflected in state practice. ${ }^{166}$ The two Review Conferences of the ENMOD Parties in 1984 and 1992 noted that there had been no violations, and no complaints or proposals to change the rules of the Convention. ${ }^{167}$ Further, many states- both parties and non-parties-haveincorporated ENMOD's rules into their military manuals, providing evidence that these states consider these rules to be legal obligations. The UNGA also includes the Convention's rules in its Guidelines on the Protection of the Environment in Times of Armed Conflict, which it invites all states to disseminate. ${ }^{168}$ At the Second ENMOD Review Conference the US stated that ENMOD mirrored "the international community's consensus that the environment itself should not be used as an instrument of war". ${ }^{169}$ Finally, general and uniform practice from

157 Tarasofsky, above n 17 , at 56.

${ }^{158}$ Schwabach, above n 15 , at 124 .

159 George Bunn “Banning Poison Gas and Germ Warfare: Should the United States Agree?" (1969) 1969 Wis. L. Rev.375 at 381; R. R. Baxter and Thomas Buergenthal "Legal Aspects of the Geneva Protocol of 1925" (1970) 64 AJIL 853 at 853; Schmitt, above n 89, at 286; Espiell, above n 20, at 423; Schafer, above n 21 , at 302 .

${ }^{160}$ UNGA Res 2603, above $\mathrm{n} 27$.

${ }^{161}$ Schmitt, above n 22, at 66.

162 Theodor Meron "The Geneva Conventions as Customary Law" (1987) 81 AJIL 348 at 348; Schmitt, ibid, at 68."Treaties and Documents by Date” (2012)International Committee of the Red Cross $<$ www.icrc.org/ihl>.

163 "Growth in United Nations Membership, 1945-Present" (2012) United Nations <www.un.org/ en/members>.

${ }^{164}$ Caggiano, above n 16 , at 493.

${ }^{165}$ Military and Paramilitary Activities in and against Nicaragua (Nicaragua v. United States of America)(Merits) [1986] ICJ Rep 113 [Nicaragua Case].

${ }^{166}$ Reyhani, above n 55, at 327; Dinstein, above n 2, at181.

167 Tarasofsky, above n 17, at 47.

${ }^{168}$ Henckaerts and 90, above n 91, at 155-156.

${ }^{169}$ United States, Statement of 15 September 1992 at the Second ENMOD Review Conference, Geneva, 14-21 September 1992. Cited in Henckaerts and Doswald-Beck, ibid, at 155. 
states reflects consensus on the prohibition of environmental destruction as a weapon in armed conflict. ${ }^{170}$

In addition to the two categories of customary rules already discussed, it is worth noting what one scholar, Koppe, considers a new direct customary rule protecting the environment during wartime that has been emerging since the 1970s. ${ }^{171}$ The principle is rooted in a global concern for theenvironment in general that was recognised formally for the first time in the 1972 Stockholm Declaration ${ }^{172}$ and has subsequently inspired innovations in the law of war that specifically protect the environment. ${ }^{173}$ These appear both as treaty provisionsand also as developments in customary international law. ${ }^{174}$

Stemming from the principle of environmental protection or responsibility, Koppeargues that there are three emerging norms of customary international law that directly protect the environment during armed conflict. These norms are: a general customary duty of care for the environment; a prohibition on causing wanton or wilful damage to the environment that is not justified by military necessity; and a prohibition on causing excessive collateral damage to the environment. The first rule resultsfrom the development of international regulations protecting the environment in general and from repeated expressions of concern. The other twoare derived from numerous references to the principles of necessity, distinction and proportionality during international hostilities. ${ }^{175}$

These three emerging norms are legally significant because they bind all states, providing legal protection for the environment during international hostilities that is independent from written treaties, and because they derive both from general worldwide concern for the environment and from fundamental principles in the law of war, such as military necessity, distinction and proportionality in the context of environmental protection during wartime. ${ }^{176}$

\section{III.Peacetime Obligations as Additional Legal Protection to the Environ- ment during Wartime}

In the aftermath of the environmental catastrophe resulting from the 1991 Gulf War, there was widespread pressure from the international community to apply general international obligations from peacetime, such as international environmental law, to strengthen the law of war and ensure better protection for the environment during armed conflict. ${ }^{177}$ Many commentators

${ }^{170}$ Henckaerts and Doswald-Beck, Ibid, at 156.

${ }^{171}$ Koppe, above n 9, at 246.

${ }^{172}$ Report of the United Nations Conference on the Human Environment A/CONF.48/14/Rev.1 (1972) [The Stockholm Declaration].

173 Examples of the treaties are the 1977 Additional Protocol I, 1977 ENMOD Convention, 1981 Certain Conventional Weapons Convention and its third Protocol, and 1997 Convention on the Prohibition of the Use, Stockpiling, Production and Transfer of Anti-Personnel Mines and on their Destruction.

${ }^{174}$ Koppe, above n 9, at 246.

175 Ibid, at 246-273.See alsoChristopher Greenwood "State Responsibility and Civil Liability for Environmental Damage Caused by Military Operations"in Richard J. Grunawalt, John E. King, and Ronald S. McClain (eds) Protection of the Environment during Armed Conflict (Naval War College, Rhode Island, 1996) 397 at 399.

${ }^{176}$ Koppe, above n 9, at 247, 273.

177 JozefGoldblat "Legal Protection of the Environment against the Effects of Military Activities" (1991) 22 Sec. Dialogue 399 at 399; Bothe, above n 64, at 103; Greenwood, above n 176, at 400; Schmitt, 
contended that the existing laws of war were inadequate. ${ }^{178}$ Aside from the international environmental regime, some also considered thatother peacetime obligations from other branches of international law, such as international human rights law ${ }^{179}$ and international law on the use of force (ius ad bellum), were relevant. ${ }^{180}$

The proposition that certain peacetime obligations that protect the environment can continue during times of war is valid. However, this does not mean that the protections offered by the existing laws of war are inadequate: as the previous section has shown, the laws of war contain a significant number of provisions, sourced both from treaties and customary laws, that protect the environment both in general and specific ways. The applicationof peacetime obligations simply providesan additional layer of legal protection for the environment during armed conflict.

In general, the notion of continuityof peacetime obligations in times of armed conflict has been subject to debate for some time. While it is widely acknowledged that this debate is on-goingand many studies have tried to resolve this issue, ${ }^{181}$ there is a general consensus that the outbreak of armed conflict does not automatically terminate peacetime treaties as discussed below.

\section{A.Applicability of Peacetime Obligations during Armed Conflicts}

Before identifying relevant peacetime obligations that protect the en-

above n 22, at 36; Bunker, above n 5, at 202-206; Sharp, above n 62, at 27; Koppe, above n 9, at 128-129; Harry H. Almond Jr. "Strategies for Protecting the Environment the Process of Coercion" (1992) 23U. Tol. L. Rev. 295 at 315; SiljaVöneky "A New Shield for the Environment: Peacetime Treaties as Legal Restraints of Wartime Damage"(2000) 9 RECIEL 20.

178 See Glen Plant (ed) Environment Protection and the Law of War; A "Fifth Geneva" Convention on the Protection of the Environment in Time of Armed Conflict (Belhaven Press, New York, 1992); Abdullah Toukan "The Gulf War and the Environment: The Need for a Treaty Prohibiting Ecological Destruction as a Weapon of War" (1991) 15(2) Fletcher F. WldAff. 95 at 99-100; Frank Barnaby "The Environmental Impact of the Gulf War" (1991) 21(4) Ecologist 166 at 172; Carolyn Stannard "Cases; Legal Protection of the Environment in Wartime" (1992) 14 Syd L. R. 373 at 376; Stephanie N. Simonds "Conventional Warfare and Environmental Protection: A Proposal for International Legal Reform" (1992) 29 Stan J Int'l L 165 at 168; Richard G. Tarasofsky "Legal Protection of the Environment during International Armed Conflict" (1993) 24 NYIL 17 at 76; Michael N. Schmitt "Green War: An Assessment of the Environmental Law of International Armed Conflict” (1997) 22 Yale J Int'l L 1. at 51; Karen Hulme "Armed Conflict, Wanton Ecological Devastation and Scorched Earth Policies: How the 1990-91 Gulf Conflict Revealed the Inadequacies of the Current Laws to Ensure Effective Protection and Preservation of the Natural Environment" (1997) 2 JC\&SL 45 at 76; Richard Falk "The Inadequacy of the Existing Legal Approach to Environmental Protection in Wartime" in Jay E. Austin and Carl E. Bruch (eds) The Environmental Consequences of War (Cambridge University Press, Cambridge, 2000) 137; Anthony Leibler "Deliberate Wartime Environmental Damage: New Challenges for International Law” (1992) 23 Cal. W. Int'l L. J. 67 at 132; SiljaVöneky "Peacetime Environmental Law as a Basis of State Responsibility for Environmental Damage Caused by War" in Jay E. Austin and Carl E. Bruch (eds) The Environmental Consequences of War (Cambridge University Press, Cambridge, 2000) 190 at 191.

${ }^{179}$ Popović, above n 66, at 88 .

${ }^{180}$ Leibler, above n 179, at 86; Bunker, above n 5, at 206; Koppe, above n 9, at 309-333.

${ }^{181}$ Lester Bernhardt Orfield "The Effect of War on Treaties" (1933) 11 Nebraska L. Bull. 276 at 276; Ian BrownliePrinciples of Public International Law (Oxford University Press, Oxford, 2003) at 592; Eritrea Ethiopia Claims Commission, Partial Award - Economic Loss Throughout Ethiopia (Ethiopia's Claim 7) (2005) 26 RIAA 445 at 455; SiljaVöneky "A New Shield for the Environment: Peacetime Treaties as Legal Restraints of Wartime Damage"(2000) 9 RECIEL 20 at 22; Michael K. Prescott "How War Affects Treaties between Belligerents: A Case Study of the Gulf War" (1993) 7 Emory Int'l L. Rev. 197 at 197; Koppe, above $n$ 9, at 336; JostDelbrück "War, Effects on Treaties" in R. Bernhardt (ed) Encyclopedia of Public International Law Volume IV (Elsevier Science Publishers, Amsterdam, 1992) 1367. 
vironment during armed conflict, it is important to examine both the treaty relationship between belligerents and non-belligerents, and thatbetween belligerents. These relationships are different to one another, and may determine whether or not they are still bound by peacetime obligations during the war.

In times of armed conflict, there is always a possibility that the territory of a third state, in particular a neighbouring state, will be affected. In this situation, the law of neutrality, discussed above, ${ }^{182}$ governs the relationship between belligerents and neutral states ${ }^{183}$ and, accordingly, peacetime treaties remain applicable between them (including their means of enforcement) $\cdot{ }^{184}$ Further, the obligation not to affect the territory of neutral states under the law of neutrality is in line with customary environmental law, which prevents states from damaging another state's environment during peacetime. ${ }^{185}$

In contrast, the application of peacetime treaties between belligerents may be severely affected during wartime. ${ }^{186}$ However, the following analysis reveals that there are treaties which continue to apply to protect the environment of belligerent states during armed conflict.

The law of war is traditionally considered by some states and commentators to be a special branch of law that applies exclusively in times of war, superseding any peacetime treaties. ${ }^{187}$ Early writers contend that the outbreak of war automatically annuls pre-existing treaties between belligerents. ${ }^{188}$ However, the current practiceof states ${ }^{189}$ and international organisations ${ }^{190}$ has dissolved the traditional dichotomy between the law of war and the law of peace. ${ }^{191}$

The primary rules in international law concerning treaties, which are codified in the 1969 Vienna Convention on the Law of Treaties, unfortunately

182 See above from [2.2.1.5].

183 Michael Bothe "The Law of Neutrality" in Dieter Fleck (ed) The Handbook of International Humanitarian Law (2nd ed, Oxford University Press, Oxford, 2008) 571 at 571.

${ }^{184}$ Simonds, above $\mathrm{n} 56$, at 188; Koppe, above n 9, at 269.Tarasofsky argued that, to the extent that the laws of neutrality permit, a state of peace exists between neutral and belligerents. Tarasofsky, above $\mathrm{n} 17$, at 32.In an armed conflict, a state is considered to be neutral if it declares its neutrality and acts in a neutral manner to all belligerents. This declaration or action of neutrality will protect the population and environment of the neutral state against any attack from the belligerents. This inviolability includes transboundary damage and, in particular, environmental damage. Violations of this protection will be regarded as an act of aggression and entail international responsibility. Roberts, above $n 147$ at 118; Plant, above $n$ 143, at 164; Al-Duaij, above n 61, 108.

185 Tarasofsky, above n 17 , at 31 .

${ }^{186}$ Koppe, above $\mathrm{n} 9$, at 336.

${ }^{187}$ Vöneky, above n 178, at 25.

${ }^{188}$ J. G. Castel “Effect of War on Bilateral Treaties: Comparative Study" (1953) 51 Mich. L. Rev. 566 at 567; Prescott, above n 182, at 197. For a similar position on state practice, see A. De La Pradelle "The Effects of War on Private Law Treaties" (1948) 2(4) ILQ 555 at 556-557.

${ }^{189}$ For detailed discussion about states' practice on this matter see Castel, ibid, at 567-572; James J. Lenoir "The Attitude of the Supreme Court as to the Effect of War on Treaties" (1935) 7 Miss. L. J.309 at 309-316; James J. Lenoir "The Effect of War on Bilateral Treaties - With Special Reference to Reciprocal Inheritance Treaty Provisions" (1946) 34 Geo. L. J.129 at 142-177; Richard Rank "Modern War and the Validity of Treaties" (1953) 38 Cornell L. Q. 321 at 341-355; Orfield, above n 182, at 283-284; Pradelle, ibid, at555-576; Prescott, above n 182, at 206-219; AnikóSzalai "Effect of the World Wars on International Treaties of Hungary" (2008) 5(2) Miskolc J. Int'l L.98.

190 The European Commission and International Maritime Organisation provide examples of recent practice in: Effects of Armed Conflicts on Treaties, Comments and Observations Received from International Organisations A/CN.4/592 (2008).

191 Vöneky, above n 178, at 25. 
do not provide a clear position on the effect of war on treaties. ${ }^{192}$ Even though this Convention is inconclusive in this matter, it does not mean that it is irrelevant. The Convention provides that the peremptory norms of general international law, or iuscogens, remain valid at all times. ${ }^{193}$ It also recognises rights of states to terminate or suspend a treaties under the rules on supervening impossibility of performance and fundamental change of circumstances, or rebus sic stantibus. ${ }^{194}$

However, based on the overall practice of the international community, it is now suggested that war does not negate all legal relations between states, and that war itself is not a phenomenon outside the realm of law. ${ }^{195}$ Instead, there are three possible effects of war on peacetime treaties: they may be terminated; suspended; or remain valid during armed conflict. Particularly, for the purpose of this thesis, it may be highlighted that there is a wide acceptance - even near unanimity - among scholars that the event of armed conflict does not automatically terminate all pre-existing treaties between warring parties. ${ }^{196}$ Thus, the claim that the law of war is a lexspecialis (special law), which exclusively applies during armed conflict, is today questionable ${ }^{197}$ and artificial. ${ }^{198}$

In addition, most studies (including the most recent study conducted by the International Law Commission (ILC) in 2011) suggest that whether or not a treaty remains valid in part or whole will be determined mainly by the intention of the parties and the object and purpose of the treaty. ${ }^{199}$ These two elements are not wholly independent of one another. If the parties' intend the treaty to apply during armed conflict, expressly stating this, it is logical to assume that the object and purpose of the treaty will be compatible with the situation of armed conflict. Similarly, if the treaty does not clearly express the intention of the parties, then an object or purpose compatible with the situation of armed conflict may suffice for it to remain valid during this time.

Consequently, scholars have identified that there are a number of peace-

${ }^{192}$ Prescott, above n 182, at 197.The Vienna Convention only provides that: "[ $\left.\mathrm{t}\right]$ he provisions of the present Convention shall not prejudge any question that may arise in regards to a treaty from (...) the outbreak of hostilities between states". Vienna Convention on the Law of Treaties, above n 86,art 73.

${ }^{193}$ Ibid, arts 53 and 64.

${ }^{194}$ Ibid, arts 61-62.

195 Rank, above n 190, at 322; Delbrück, above n 182, at 1368-1369.

196 Cecil J.B. Hurst "The Effect of War on Treaties" (1921) 2 BYIL37 at 38; Harvard Research in International Law "Law of Treaties: Effect of War" (1935) 29 AJIL 657 at 1183-1204 [Harvard Research in International Law]; A.D. McNair The Law of Treaties (Clarendon Press, Oxford, 1961) at 697; BengtBroms"The Effects of Armed Conflicts on Treaties"(1985) Institute of International Law <www.idi-iil. org/idiE/navig_res_chon.html> (the 1985 IDI Resolution), art. 2; Delbrück, above n 182, at 1369-1371; The Effect of Armed Conflict on Treaties: An Examination of Practice and Doctrine; Memorandum by the Secretariat A/CN.4/550 (2005) [the 2005 UN Secretariat Study]; Orfield, above n 182, at 281; Rank, above n 190, at 322; Castel, above n 189, at 566; Lenoir "The Effect of War on Bilateral Treaties", above n 190, at 142; Prescott, above n 182, at 223; Article 3 of the Draft Articles on Effects of Armed Conflict on Treaties. Report of the International Law Commission to the General Assembly on the work of its Sixty-third session A/66/10 Supp. No.10 (2011) [the 2011 ILC Draft] at 175. See also Oliver Dörr and Kirsten Schmalenbach (eds) Vienna Convention on the Law of Treaties: A Commentary (Springer, New York, 2012) at 1257-1258.

${ }^{197}$ Lijnzaad and Tanja, above n 43, at 172.

198 Tarasofsky, above n 17, at 62.

199 Hurst, above n 197, at 47; Rank, above n 190, at 325; Harvard Research in International Law, above $n$ 197, 1183; McNair, above n 197, at 698; the 1985 IDI Resolution, above n 197, art 3; the 2011 ILC Draft, above n 197, draft arts. 4 and 6. 
time treaty categories that remain applicable during hostilities between warring parties. They are:

(a) treaties relating to the law of armed conflict;

(b) treaties regulating a permanent regime or status, also called objective regimes (including treaties establishing or modifying land and maritime boundaries); ${ }^{200}$

(c) multilateral law-making treaties. ${ }^{201}$

(d) human rights treaties; and

(e) treaties relating to the international protection of the environment. ${ }^{202}$

From these categories, some treaties from human rights law and environmental laware relevant to this thesis because they could strengthen the law of war to protect the environment during armed conflict.

In addition to these two sources of law (human rights and environmental law treaties), there is a special peacetime regime which may be argued to offer indirect but significant protection for the environment in times of war - international law on the use of force (ius ad bellum). This is due to the application of ius ad bellumlaw during the 1991 Gulf War ${ }^{203}$ in the formof the UN Security Council's (UNSC) Resolution 687. ${ }^{204}$ Identification and examination of environmental protection provisions from human rights law, environmental law and ius ad bellum will be provided in the following sections.

\section{B.International Human Rights Law}

In principle, international human rights treaties remain valid in times both of peace and armed conflict, ${ }^{205}$ particularly "non-derogable" provisions

${ }^{200}$ Vöneky notes that this category of treaties continues to apply during wartime because such treaties "establish a territorial order in the general interest of the international community, such as treaties providing for the demilitarisation or neutralisation of zones or the internationalisation of waterways". Vöneky, above n 178, at 23.

201 According to McNair, multilateral law-making treaties are those that "create rules of international law for regulating the future conduct of the parties without creating an international regime, status, or system. It is believed that these treaties survive a war, whether all the contracting parties or only some of them are belligerent". McNair, above $n$ 197, at 723.

${ }^{202}$ See McNair, above n 197, at 703-723; the 1985 IDI Resolution, above n 197, arts 4-6; Delbrück, above n 182, at 1370; the 2005 UN Secretariat Study, above n 197, at 14-40; the 2011 ILC Draft, above $n$ 197, draft art 7 and annex.

${ }^{203}$ According to Low and Hodgkinson, "[t]he prohibition against the use of force in article 2(4) is capable of protecting any object, including the environment, which might be affected by the unlawful use of force. Article 2(4) is aimed at the protection of the 'territorial integrity or political independence of any state.' In other words, it protects state sovereignty which extends to protection of a state's people, property, and environment", above n 15 , at 459.

204 Resolution 687 reaffirmed that: "Iraq, without prejudice to the debts and obligations of Iraq arising prior to 2 August 1990, which will be addressed through the normal mechanisms, is liable under international law for any direct loss, damage, including environmental damage and the depletion of natural resources, or injury to foreign Governments, nationals and corporations, as a result of Iraq's unlawful invasion and occupation of Kuwait" (emphasis added). SC Res 687, UN Doc S/Res/687 (1991) [UNSC 687] at [16].

${ }^{205}$ Nuclear Weapons Advisory Opinion, above n 141, at 240; The 1985 IDI Resolution, above n 197, art 4; J Jeremy Marsh "Rule 99 of the Customary International Humanitarian Law Study and the Relationships between the Law of Armed Conflict and International Human Rights Law" (2009) 5 Army Law.18 at 18; Koppe, above n 9, at 346; Advisory Service on International Humanitarian Law "International Humanitarian Law and International Human Rights Law: Similarities and differences" (2003) International Committee of the Red Cross <www.ehl.icrc.org $>$. 
of some treaties. ${ }^{206}$ The application of human rights law during armed conflict creates an interesting relationship between human rights law and international humanitarian law or the law of war. ${ }^{207}$ In addition, human rights treaties are considered to be applicable during wartime because their main object is "the protection of a common good in the interest of the state community as a whole", which is comparable to treaties establishing objective regimes. ${ }^{208}$

The right to a healthy environment has been an important subject in human rights law. ${ }^{209}$ This is based on the proposition that environmental protection is an indispensable element of, and a pre-requisite to, the enjoyment of human rights. ${ }^{210}$ Furthermore, the close relationship between environmental protection and human rights has been the subject of much academic discussion. ${ }^{211}$ States in general have recognised this relationship through paragraph 1 of the 1972 Stockholm Declaration on the Human Environment.

${ }^{206}$ For example, art 4(1) of theInternational Covenant on Civil and Political Rights(opened for signature 19 December 1966, entered into force 10 October 1976) [ICCPR] stipulates that state parties may derogate some of their obligations under the Convention in times of public emergency that threaten the life of the nation. This right of derogation, however, must meet other criteria before it is taken. Derogation should be taken in a non-discriminatory way and only "to the extent strictly required by the exigencies of the situation". However, this article also excludes a number of specific human rights from derogation and makes these rules remain in force for state parties at all times including times of armed conflict. These rules are: the right to life, prohibition of torture or cruel, inhuman or degrading treatment or punishment, prohibition of slavery and servitude and the prohibition of retroactive criminal laws, equality before the law and right to freedom of thought, conscience and religion.

${ }^{207}$ The examination of their relationship is outside the scope of this study and has been subject to wide discussion among scholars. SeeIain Scobbie "Principle or Pragmatics? The Relationship between Human Rights Law and the Law of Armed Conflict" (2010) 14 JC\&SL 449; Marko Milanović "A Norm Conflict Perspective on the Relationship between International Humanitarian Law and Human Rights Law" (2010) 14 JC\&SL 459; Robert Cryer "The Interplay of Human Rights and Humanitarian Law: The Approach of the ICTY" (2010) 14 JC\&SL511; Robert Kolb "Human Rights and Humanitarian Law" in R. Wolfrum (ed) Max Planck Encyclopedia of Public International Law (2008) <www.mpepil.com>; RuonaIguyovwe "The Interplay between International Humanitarian Law and International Human Rights Law" (2008) 34 CLB 749; CordulaDroege "The Interplay between International Humanitarian Law and International Human Rights Law in Situations of Armed Conflict" (2007) 40 Israel L. Rev. 310; Raúl Emilio Vinuesa "Interface, Correspondence and Convergence of Human Rights and International Humanitarian Law" (1998) 1 YIHL69; Louise Doswald-Beck and Sylvain Vité "International Humanitarian Law and Human Rights Law" (1993) 33(293) IRRC 94; Dietrich Schindler "Human Rights and Humanitarian Law: Interrelationship of the Laws" (1982) 11 Am. U. L. Rev. 935 at 937, 941-943. The International Committee of the Red Cross (ICRC) argues that international humanitarian law and international human rights law are complementary. Both of them focus on protecting the lives, health and dignity of individuals albeit from a different angle. International Committee of the Red Cross International Humanitarian Law: Answers to Your Questions (International Committee of the Red Cross, Genève, 2002) at 36.

${ }^{208}$ Vöneky, above n 178, at 25.

209 Dinah Shelton "Human Rights, Environmental Rights, and the Right to Environment" (1991) 28 Stan.J. Int'l L. 103 at 138; Philippe Antoine 'International Humanitarian Law and the Protection of the Environment in Time of Armed Conflict' (1992) 32 IRRC 517 at 520.

${ }^{210}$ Vid Vukasovic "Protection of the Environment: One of the Key Issues in the Field of Human Rights" (1990) 59 RevistaJurid. Univ. Puerto Rico 889 at 892.

211 See Neil A.F. Popović "In Pursuit of Environmental Human Rights: Commentary on the Draft Declaration of Principles on Human Rights and the Environment" (1996) 27(3) Colum. Hum. Rts L. Rev 487; Alan E. Boyle "The Role of International Human Rights Law in the Protection of the Environment" in Alan E. Boyle and Michael R. Anderson (eds) Human Rights Approaches to Environmental Protection (Clarendon Press, Oxford, 1998) 43; Michael Burger "Bi-Polar and Polycentric Approaches to Human Rights and the Environment" (2003) 28 Colum. J. Envtl L.371; Karrie Wolfe "Greening the International Human Rights Sphere? Environmental Rights and the Draft Declaration of Principles on Human Rights and the Environment" (2003) 9 Appeal: Rev. Current L. \& L. Reform45. 
It affirms that: ${ }^{212}$

$[\mathrm{m}]$ an has the fundamental right to freedom, equality and adequate conditions of life, in an environment of a quality that permits a life of dignity and well-being, and he bears a solemn responsibility to protect and improve the environment for present and future generations.

Two decades later, international protection for the environment was again closely linked with human rights ${ }^{213}$ in Principle 1 of the Rio Declaration which reads: "[h]uman beings are at the centre of concerns for sustainable development. They are entitled to a healthy and productive life in harmony with nature". 214

Following the Rio Declaration, the UN Commission on Human Rights conducted a study of human rights and the environment in 1994. Its final 'Ksentini Report' examined the relationship between human rights and the environment and provided draft principles for legal framework of this relationship. The importance of the close relationship between human rights and the environment is expressly stated in Part 1: "[h] uman rights, an ecologically sound environment, sustainable development and peace are interdependent and indivisible".215

Within treaty law, explicit reference of environmental protection can be found in Article 12 of the 1966 International Covenant on Economic, Social and Cultural Rights (ICESCR). It recognises the "right of everyone to the enjoyment of the highest attainable standard of physical and mental health" including the right to "the improvement of all aspects of environmental and industrial hygiene". ${ }^{216}$ Apart from this provision, there is no independent right to a sound environment in international law. ${ }^{217}$ However, some scholars argue that environmental rights can be derived from other existing treaties especially the rights to life, private life, property and access to justice ${ }^{218}$ under the 1966 International Covenant on Civil and Political Rights (ICCPR), ${ }^{219}$ the 1950 European Convention on Human Rights, ${ }^{220}$ and the 1969 Inter-American Convention on Human Rights. ${ }^{221}$

Walter Kälin, a special rapporteur of the UN Commission of Human

${ }^{212}$ The Stockholm Declaration, above n 173.

${ }^{213}$ Eva M. KornickerUhlmann "State Community Interests, Jus Cogens and Protection of the Global Environment: Developing Criteria for Peremptory Norms” (1999) 11Geo. Int'l Envtl L. Rev. 101 at 127.

${ }^{214}$ Report of the United Nations Conference on the Environment and Development A/CONF.151/26 (Vol.I) (1992) [The Rio Declaration].

${ }^{215}$ FatmaZohraKsentiniFinal Report of the Special Rapporteur on Human Rights and the Environment E/CN.4/Sub.2/1994/9 (1994) [The 1994 Ksentini Report] at [74].

${ }^{216}$ International Covenant on Economic, Social and Cultural Rights (opened for signature 19 December 1966, entered into force 3 January 1976) [ICESCR], art 12.

${ }^{217}$ Vöneky, above n 178, at 24.

218 This contention has been based on observations of cases before the European Court of Human Rights, UN Human Rights Committee and the Inter-American Commission and Court of Human Rights. See Patricia Birnie, Alan Boyle and Catherine RedgwellInternational Law \& the Environment (3rd ed, Oxford University Press, Oxford, 2009) at 282-286.

${ }^{219}$ ICCPR, above n 207, arts 6(1), 14(1), 17.

${ }^{220}$ Convention for the Protection of Human Rights and Fundamental Freedoms (opened for signature 4 November 1950, entered into force 3 September 1953), arts 2, 6(1), 8; Protocol No. 1 to the Convention for the Protection of Human Rights and Fundamental Freedoms (opened for signature 20 March 1952, entered into force 1 November 1998), art 1.

${ }^{221}$ American Convention on Human Rights(opened for signature 22 November 1969, entered into force 18 July 1978), arts 4(1), 8(1), 11(2), 21. 
Rights in the 1991 Kuwait case, stated: ${ }^{222}$

[n] ot only in peacetime but also in times of armed conflict, the deliberate causing of large-scale environmental damage which severely affects the health of a considerable proportion of the population concerned, or creates risks for the health of future generations, amounts to a serious violation of (...) article 12 of the International Covenant on Economic, Social and Cultural Rights.

In addition, one of the draft principles of the Ksentini Report above particularly stressed the importance of compliance with international humanitarian law in order to protect human rights and the environment. ${ }^{223}$ It stipulated:224

[s]tates and all other parties shall avoid using the environment as a means of war or inflicting significant, long-term or widespread harm on the environment, and shall respect international law providing protection for the environment in times of armed conflict and cooperate in its further development.

Based on this analysis, most provisions from human rights treaties remain applicable during wartime including those that provide protection to the environment. Therefore, belligerent states should ensure that they respect not only the protection of (narrowly conceived) human rights but also to the environment under the regime of human rights law.

\section{C.International Environmental Law}

While most environmental treaties are silent on their wartime applicability, and may contain clauses to preclude their application to ships or aircraft entitled to sovereign immunity, ${ }^{225}$ the general application of international environmental treaties during armed conflict between belligerents has received growing support from the international community. ${ }^{226}$ As discussed below, this proposition is based on the fact that the object and purpose of some environmental treaties is compatible and consistent with the event of armed conflict and thus termination or suspension of their implementation is irrelevant during wartime.

Apart from the effect of war on treaties in general, some scholars havefocused their discussion on the question of whether, and to what extent, peacetime environmental treaties continue to apply during armed conflict. ${ }^{227}$

Among these scholars, Vöneky has presented a convincing argument concerning the applicability of environmental treaties during armed con-

${ }^{222}$ Walter Kälin "Report on the Situation of Human Rights in Kuwait under Iraqi Occupation” in Walter Kälin (ed) Human Rights in Times of Occupation: The Case of Kuwait (Stämpfli for Law Books in Europe, Berne, 1994) 69 at 119.

223 The 1994 Ksentini Report, above n 216, at 27-30.

${ }^{224}$ Ibid, Principle 23.

${ }^{225}$ Sands, above n 130, at 309; Birnie et al, above n 219, at 207.

${ }^{226}$ See fn178 above.

${ }^{227}$ UNEP 2009, above n 109, at 43-45; Vöneky, above n 178; Schmitt, above n 22, at 36-51; Sonja Ann JozefBoelaert-Suominen "International Environmental Law and Naval War; The Effect of Marine Safety and pollution Conventions during International Armed Conflict" (Newport Paper No.15, Naval War College, 1997) at 91-133; John P. Quinn, Richard T. Evans, and Michael J. Boock "United States Navy Development of Operational-Environmental Doctrine" in Jay E. Austin and Carl E. Bruch (eds) The Environmental Consequences of War (Cambridge University Press, Cambridge, 2000) 156 at 164. 
flict. By analogous application, ${ }^{228}$ Vöneky argues that at least two categories of environmental treaty remain valid for the belligerents. These are environmental treatiesprotecting areas beyond national jurisdiction ${ }^{229}$ and "common goods", ${ }^{230}$ which aim to serve the interests of the state community as a whole,without any direct advantage to a particular state. ${ }^{231}$ Vöneky asserts that they are similar or comparable to treaties creating a permanent regime or status and treaties protecting fundamental human rights respectively, ${ }^{232}$ and thus continue to apply and bind the belligerents during armed conflict.It is considered that this approach is sound in theory and also has the advantage that using these categories to identify environmental treaties, which remain applicable in wartime, simplifies and clarifies the process, making it easier to invoke them on belligerents during wartime.

In addition to Vöneky's approach, it may also be argued that despite the parties not intending to be bound during times or war, these environmental provisions remain valid because their object and purpose are compatible with the event of armed conflict. Most of these treaties are multilateral treaties with governing issues or objects that do not have benefit to a particular state or states but are for the international community as a whole. Accordingly, international cooperation to achieve common goals becomes the primary objective even during times of armed conflict. Therefore, they remain applicable and bind state belligerents during armed hostilities.

It may be not self-evident that violations of these treaties above will affect other states directly. Nevertheless, since they serve the interests of the state community as a whole, statesthat were not directly affected could invoke provisions against states that violate the relevant treaties. For such situation, international law provides that these non-specifically affected states may invoke clauses if the violation affects a group of states including that state, or if the "obligation breached is owed to the international community as a whole".233

Further, the international tribunal has confirmed the possibility of such invocation of responsibility recently. The Seabed Disputes Chamber of the International Tribunal for the Law of the Sea (ITLOS) states that, in the case of damage, each state party may claim "compensation in light of the ergaomnescharacter of the obligations relating to preservation of the environment of the high seas and in the Area". ${ }^{234}$ In addition, the Chamber also suggests that the International Seabed Authority may be entitled to claim similar compensation because it acts "on behalf of mankind". 235

\footnotetext{
${ }^{228}$ For more discussion about analogy in international law, see Josef L. Kunz "International Law by Analogy" (1951) 45 AJIL 329; SiljaVöneky "Analogy in International Law" in R. Wolfrum (ed) (2008) Max Planck Encyclopedia of Public International Law <www.mpepil.com>.

${ }^{229}$ These treaties cover areas such as the deep seabed, the high seas and the Antarctic.

230 These "goods" include the climate, the ozone layer, biodiversity, world heritage sites, wild and endangered species, and wetlands with international importance.

${ }^{231}$ Vöneky, above n 178, at 21.

232 Ibid, at 23-28.

233 The 2001 ILC Draft Articles on Responsibility of States for Internationally Wrongful Acts and Commentaries. Report of the International Law Commission to the General Assembly on the work of its Fifty-third session A/56/10 (2001), art 48(1).

${ }^{234}$ Responsibilities and Obligations of States Sponsoring Persons and Entities with Respect to Activities in the Area (Advisory Opinion) (Case No. 17) [2011] ITLOS at [180].

${ }^{235}$ Ibid. For more discussion on this advisory opinion, see Peter Holcombe Henley "Minerals and
} 


\section{Treaties Protecting Areas beyond National Jurisdiction}

Two key examples of international environmental agreements relating to areas beyond national jurisdiction are the United Nations Convention on the Law of the Sea (UNCLOS) ${ }^{236}$ and the Antarctic Treaty. ${ }^{237}$ Examination of these treaties revealsthat they were established in the general interest of the international community as a whole and are accordinglyhighly likely to continue to apply in the event of armed conflict.

In protecting areas beyond national jurisdiction, UNCLOS covers areas such as the seabed (the Area) and the high seas in the provisions in Parts XI and XII respectively. Furthermore, these provisions contain no indicationthat the parties did not intend them to apply in wartime.

Part XI of UNCLOS protects the Area from military activities in the common interest. Article 136 states that the Area and its resources are the "common heritage of mankind".238The clear purpose of these provisions is to protect the seabed in the interests of present and future generations of people. Subsequent provisions confirm this position by prohibiting states from making claims or exercising sovereignty or "sovereign rights" over the Area or its resources, by determining that "[a]ll rights in the resources of the area are vested in mankind as a whole"239 and by requiring that activities in theArea be conducted for "the benefit of mankind as a whole". ${ }^{240}$ At the institutional level, UNCLOS confers on the International Seabed Authority the right to manage resources of the areas in which the interests of mankind as In addition, art 141 offers environmental protection by restricting activities in the Area to those done exclusively for "peaceful purposes". ${ }^{241}$ UNCLOS does not contain a specific definition of "peaceful purposes". However, the meaning of this phrase may be extrapolated from arts 88 and 301 . Article 88 states that "[t]he high seas shall be reserved for peaceful purposes" 242 and art 301 narrowly states: ${ }^{243}$

[i]n exercising their rights and performing their duties under this Convention, state parties shall refrain from any threat or use of force against the territorial integrity or political independence of any state, or in any other manner inconsistent with the principles of international law embodied in the Charter of United Nations.

From these provisions, it can be understood that the protection provided by art 141 is not against all military activity, but has to be interpreted as

Mechanisms: The Legal Significance of the Notion of the 'Common Heritage of Mankind' in the Advisory Opinion of the Seabed Disputes Chamber" (2011) 12 Melb. J. Int'l L. 373.

${ }^{236}$ United Nations on the Law of the Sea (opened for signature 10 December 1982, entered into force 16 November 1994) [the 1982 UNCLOS].

${ }^{237}$ The Antarctic Treaty (opened for signature 1 December 1959, entered into force on 23 June 1961) [the 1959 Antarctic Treaty].

${ }^{238}$ The 1982 UNCLOS, above $\mathrm{n} 237$, art 136.

${ }^{239}$ Ibid, art 137(1) and (2).

${ }^{240}$ Ibid, art 140(1).

241 It is stated: "[t]he Area shall be open to use exclusively for peaceful purposes by all states, whether coastal or land-locked, without discrimination and without prejudice to the other provisions of this Part". Ibid, art 141.

${ }^{242}$ Ibid, art 88. According to UNEP, this provision seems to proscribe any hostile activities, such as those which are military in nature, without specifying the extent of harm to the environment of the high seas as areas beyond national jurisdiction.UNEP 2009, above n 109, at 36 .

${ }^{243}$ The 1982 UNCLOS, above n 237, art 301. 
a prohibition of aggressive activities in light of the meaning of the UN Charter (see art 2(4)). It is apparent that aggressive military activities that might lead to an armed conflict in the Area may be contrary to the interest of the international community as a whole. The possibility of this situation implicitly shows that these provisions are compatible with, and remain valid, in the event of armed conflict.

Besides the Area, provisions to protect the environment in the interests of the international community as a whole are also provided in Part XII. Here, states have the obligation, under art 192, "to protect and preserve the marine environment". ${ }^{244}$ This article obliges all states to protect the marine environment per sebecause it does not refer to national interests or parties. Thus, this provision arguably represents an obligation that serves the interest of the international community as a whole. ${ }^{245}$ Since art 192 protects the environment in the common interest, Vöneky argued that any article that may serve national interests, such as art 194(2), ${ }^{246}$ should be interpreted in the light of art 192's general rule as a means to protecting the marine environment in the general interest. ${ }^{247}$

In addition to marine protection beyond national jurisdiction, states are also under obligations to conserve sustainable fisheries and marine life conservation in the area of high seas. ${ }^{248}$ Under these rules, party statesare obliged to control fishing within their territories in order to maintain sustainable levels of fish stocks in their waters or in the regional waters surrounding their territories. It is difficult to see how state parties could justifiably argue that their obligations or indeed UNCLOS' duties in relation to high seas are incompatible with a state of war.

It seems that art 236, which provides an exemption clause for military devices, ${ }^{249}$ renders UNCLOS provisions inapplicable during armed conflict. Sucha challenge may, however, be laid to rest by reference to the rest of that provision, which requires each state to "ensure (...) that such vessels or aircraft act in a manner consistent, so far as is reasonable and practicable, with this Convention". ${ }^{250}$ Therefore, it can be argued that environmental damage from the conduct of aircraft and warships during armed conflict is not wholly exempted by art 236 because the member states remain obliged to make sure that such vessels or aircrafts act according to UNCLOS.

It therefore seems that the provisions in UNCLOS for the protection of the Area and the marine environment aim to serve the interests of the international community as a whole. Given the absence of any indication that the

244 Ibid, art 192.

245 In commenting on this article, Kiss and Shelton argued that "the general interest of all mankind is recognised in this way, which is higher than the interests and the sovereignty of individual states and independent of any harm or damage which may be suffered as a result of the activities of other states". Alexandre Kiss and Dinah Shelton "Systems Analysis of International Law: A Methodological Inquiry" (1986) 68 NYIL 45 at 64; see also Vöneky, above n 178, at 26.

246 Article 194(2) stipulates "[s]tates shall take all measures necessary to ensure that activities under their jurisdiction or control are so conducted as not to cause damage by pollution to other states and their environment, (...)". The 1982 UNCLOS, above n 237.

${ }^{247}$ Vöneky, above n 178 , at 26.

248 The 1982 UNCLOS, above $\mathrm{n} 237$, arts 117-120.

${ }^{249}$ Article 236 provides that: "the provisions of this convention regarding the protection and preservation of the marine environment do not apply to any warship". Ibid, art 236.

250 Ibid. 
parties did not intend these provisions to apply in times of war, it can be argued that these provisions remain valid during armed conflicts and are binding on belligerent states.

Another importantexample of an environmental treaty that serves the interests of the international community is the Antarctic Treaty. Its preamble confirms that: "it is in the interest of all mankind that Antarctica shall continue forever to be used exclusively for peaceful purposes and shall not become the scene or object of international discord". ${ }^{251}$ Further, the protection provision of this Treaty can be found in art I which states: ${ }^{252}$

1. [A]ntarctica shall be used for peaceful purposes only. There shall be prohibited, inter alia, any measures of a military nature, such as the establishment of military bases and fortifications, the carrying out of military manoeuvres, as well as the testing of any type of weapons.

2. [t]he present treaty shall not prevent the use of military personnel or equipment for scientific research or for any other peaceful purpose.

In addition, art XIII paragraph 1 stipulates that theTreaty "shall be open for accession by any state which is a member of the United Nations, or by any other state....253 Further, the Consultative Parties emphasised their responsibility to protect the Antarctic area against any activitythat might have consequences of global significance. ${ }^{254}$ In 1991, the Consultative Parties further agreed to designate Antarctica as a special protected area devoted only to peace and science. ${ }^{255}$

From such references, it is clear that the Antarctic Treaty protects the Antarctic area in the interests of the international community. ${ }^{256}$ The permanent special status designation of the Antarctic has shown states' intention to protect certain areas beyond national jurisdiction without any time limitation. Thus, it is similar to a treaty establishing a permanent regime or status, ${ }^{257}$ and so continues to bindbelligerents during armed conflict.

\section{Treaties Protecting Common Goods}

As discussed previously, ${ }^{258}$ human rights treaties remain valid

${ }^{251}$ The 1959 Antarctic Treaty, above n 238, preamble.

${ }^{252}$ Ibid, art I.

${ }^{253}$ Ibid, art XIII(1).

${ }^{254}$ Catherine Redgwell "The Protection of the Antarctic Environment and the Ecosystem Approach" in Michael Bowman and Catherine Redgwell (eds) International Law and the Conservation of Biological Diversity (Kluwer Law International, London, 1996) 109 at 113.

${ }^{255}$ This is stipulated in a protocol to the Antarctic Treaty with commonly known as the Madrid Protocol. Protocol on Environmental Protection to the Antarctic Treaty(opened for signature 4 October 1991, entered into force 14 January 1998).

${ }^{256}$ Having established this legal position, Vöneky also argues that other treaties within the Antarctic Treaty System also serve the interest of the international community as a whole, such as the Convention for the Conservation of Antarctic Seals, the Convention on the Conservation of Antarctic Marine Living Resources, the Convention on the Regulation of the Antarctic Mineral Resource Activities and the Protocol on Environmental Protection to the Antarctic Treaty. Vöneky, above n 178, at 27, fn 83.

${ }^{257}$ As noted previously, treaties creating a permanent regime or special status such as administration of a territory, establishing a boundary, and creating an international organisation will be unaffected during wartime among its member parties. The 2005 UN Secretariat Study, above n 197,at 20; McNair, above n 197, at 704, 720; Delbrück, above n 182, at 1370; Anthony AustModern Treaty Law and Practice (Cambridge University Press, Cambridge, 2000) at 244; Jan Hendrik Willem VerzijlInternational Law in Historical Perspective (MartinusNijhoff, Leiden, 1973) at 371-372.

${ }^{258}$ See above at [3.2]. 
during armed conflict because they regulate the universal interests of the international community.By analogy, it has been argued that environmental treaties with the object of protecting common goods or global environmental resources are of a similar character and should also remain valid during times of war. This is because these treaties are specificallyintended to protect environmental goods ${ }^{259}$ which are considered to be indispensable for human survival;to maintaining an environmental balance in the interests of the state community as a whole; ${ }^{260}$ and to seek "the protection of territorial integrity or other national interests as only a side-effect". ${ }^{261}$

One notable example of this type of treaty is the UN Framework Convention on Climate Change. ${ }^{262}$ This Convention acknowledges that "the change in the earth's climate and its adverse effects are a common concern of humankind", and state parties determine "to protect the climate system for present and future generations". ${ }^{263}$ These statements clearly showthat the common interest of protecting the global climate hasbecome a priority. ${ }^{264}$ The Convention goes on to recognise that the protection of the climate system is for the benefit of present and future generations of humankind, ${ }^{265}$ and that state parties have common responsibilities in reaching this goal. ${ }^{266}$ This Convention stresses the importance of promoting sustainable development (which is generally characterised as "development that meets the needs of the present without compromising the ability of future generations to meet their own needs") ${ }^{267}$ as national policy. ${ }^{268}$ In a similar way to human rights treaties, the implementation of duties imposed by the Convention does not lead to any direct advantage to a particular state party, nor reciprocal benefits or rights. ${ }^{269}$

Similar references are found in some treaties, indicatingthat their main intention is to protect global or common goods for the interest of the international community as a whole. They include: the Convention on International Trade in Endangered Species of Wild Fauna and Flora; ${ }^{270}$ the Convention on the Conservation of Migratory Species of Wild Animals; ${ }^{271}$ the Convention on

${ }^{259}$ The protection of "common goods" is different from protection of areas beyond national jurisdiction because common goods may be located within national jurisdiction, but nonetheless the purpose of their protection is for the benefit of the international community as a whole.

${ }^{260}$ RüdigerWolfrum "Purposes and Principles of International Environmental Law” (1990) 33 GYIL 308 at 327

${ }^{261}$ Vöneky, above n 178 , at 27-28.

${ }^{262}$ United Nations Framework Convention on Climate Change(opened for signature 4 June 1992, entered into force on 21 March 1994) [the 1992 UNFCCC].

${ }^{263}$ Ibid, preamble, first and last paragraphs.

${ }^{264}$ Vöneky, above n 178, at 28.

265 The 1992 UNFCCC, above n 264, art 3 (1).

${ }^{266}$ Ibid, arts 3 (1) and 4.

${ }^{267}$ Report of the World Commission on Environment and Development A/42/427 (1987) at 54.

268 Ibid, art 3 (4).

${ }^{269}$ Vöneky, above n 178 , at 28 .

270 This Convention was adopted in 1973 and for the purpose of: "[r]ecognising that wild fauna and flora in their many beautiful and varied forms are an irreplaceable part of the natural systems of the earth which must be protected for this and the generations to come". Convention on International Trade in Endangered Species of Wild Fauna and Flora (opened for signature 3 March 1973, entered into force on 1 July 1975), Preamble.

${ }^{271}$ The intention to serve the international community's interest of this Convention is stipulated in the first two paragraphs of its preamble: "[r]ecognising that wild animals in their innumerable forms are an irreplaceable part of the earth's natural system, which must be conserved for the good of mankind; Aware 
Biological Diversity; ${ }^{272}$ the Vienna Convention for the Protection of the Ozone Layer; ${ }^{273}$ the World Heritage Convention; ${ }^{274}$ and the Convention on Wetlands of International Importance (commonly known as the Ramsar Convention). ${ }^{275}$

The World Heritage Convention, in particular,contains other indications that it is compatible with the event of armed conflict.Article 11(4) obligesstate parties to maintain a "list of World Heritage in Danger"276including such "cultural and natural heritage as is threatened by serious and specific dangers, such as (...) the outbreak or the threat of an armed conflict" ${ }^{277}$ This Convention was invoked during the Israel-Lebanon $\mathrm{War}^{278}$ when Israel's bombing campaign was alleged to amount to a violation. The campaign caused significant damage to UNESCO's protected world heritage sites, such as the Byblos and Baalbeck archaeological sites, Chamaa mausoleum and a tomb dating from the Roman era in Tyre. ${ }^{279}$ Together with the Ramsar Convention, the United

that each generation of man holds the resource of the earth for future generations and has an obligation to ensure that this legacy is conserved and, where utilised, is used wisely". Convention on the Conservation of Migratory Species of Wild Animals (opened for signature 23 June 1979, entered into force 1 November 1983), Preamble.

272 The parties to the Convention on Biological Diversity expressly affirm that "the conservation of biological diversity is a common concern of humankind". Convention on Biological Diversity (opened for signature 5 June 1992, entered into force on 29 December 1993), Preamble, paragraph 3.

${ }^{273}$ The parties to the Vienna Convention and Montreal Protocol have agreed to cut production and consumption of ozone depleting substances because of "potentially harmful impact on human health and the environment through modification of the ozone layer" and are "[d]eterminedto protect human health and the environment against adverse effects resulting from modifications of the ozone layer". Convention for the Protection of the Ozone Layer (opened for signature 22 March 1985, entered into force on 22 September 1988). See also Montreal Protocol on Substances that Deplete the Ozone Layer (opened for signature 16 September 1987, entered into force on 1 January 1989) as either adjusted and/or amended in London 1990, Nairobi 1991, Copenhagen 1992, Vienna 1995, Montreal 1997, and Beijing 1999, Protocol to the Convention for the Protection of the Ozone Layer(opened for signature 22 March 1985, entered into force on 22 September 1988). As of August 2012, nearly all states in the world have become parties to the Montreal Protocol on Substances that Deplete the Ozone Layer showing the importance of the matter as an issue of common concern among nations. Ozone Secretariat Status of Ratification (2012) United Nations Environmental Programme <http://ozone.unep.org>.

274 This Convention was adopted in consideration of the fact that "deterioration or disappearance of any item of the cultural or natural heritage constitutes a harmful impoverishment of the heritage of all the nations of the world" and "parts of the cultural or natural heritage are of outstanding interest and therefore need to be preserved as part of the world heritage of mankind as a whole". Convention Concerning the Protection of the World Cultural and Natural Heritage (opened for signature 23 November 1972, entered into force on 17 December 1975), Preamble [the 1972 World Heritage Convention].

275 The parties to the Ramsar Convention "stem the progressive encroachment on and loss of wetlands now and in the future". Convention on Wetlands of International Importance especially as Waterfowl Habitat (opened for signature 2 February 1971, entered into force on 21 December 1975), Preamble, paragraph 4. In an arguable reference to situations of armed conflict, this Convention recognises the right of state parties to "delete or restrict" the boundaries of listed protected wetlands because of "urgent national interests". Ibid, art 2(5).

276 This is "a list of the property appearing in the World Heritage List for the conservation of which major operations are necessary and for which assistance has been requested under this Convention". The 1972 World Heritage Convention, above n 276, art 11(4).

277 Ibid (emphasis added). More example of implementation of "Danger List", see Alexander Gillespie Protected Areas and International Environmental Law (MartinusNijhoff Publishers, Leiden, 2007) at 227-228.

${ }^{278}$ For the detail of this armed conflict,see Yaël Ronen "Israel, Hizbollah, and the Second Lebanon War" (2006) 9 YIHL 362; Victor Kattan "Israel, Hezbollah and the Conflict in Lebanon: An Act of Aggression or Self-Defense?" (2006) 14 Hum. Rts Brief 26.

${ }^{279}$ Report of the Commission of Inquiry on Lebanon Pursuant to Human Rights Council Resolution 
Nations Environment Programme (UNEP) argues that it may be easier to apply these two particular Conventions during armed conflicts than other agreements from environmental law because they provide "real guidance to commanders on the battlefield or to be enforced after the event".280

Finally, since the objects of all the treaties in this section are problems common to all membersof the international community, it can be considered that inter-state cooperation (to achieve common goals) is a primary objective even during times of war. Therefore, it can be argued that the implementation of these rules and principlesdoes not cease in the event of armed conflict. Further, as treaties that serve the interest of the international community in general, in a similar way to human rights treaties, they continue to apply to bind belligerent states during times of armed conflict. ${ }^{281}$

\section{International Law on the Use of Force (Ius ad Bellum)}

Following human rights and environmental laws, ius ad bellum (the law on the use of force) is the third category of general international peacetime law that offers environmental protection during armed conflict. In the aftermath of the 1991 Gulf War, the UNSC held Iraq liable for war consequences including environmental damage, mainly because of Iraq's violation of ius ad bellum. ${ }^{282}$ Even though environmental protection under this regime may be both subsidiary and indirect, ${ }^{283}$ this attribution of wrongdoing should be welcomed for its potential precedent-setting value.

Ius ad bellumcomprises a body of international law that governs the resort to armed force as an instrument of national policy. ${ }^{284}$ In modern times, art 2(4) of the UN Charter ${ }^{285}$ has become the source of this law which is also considered to be iuscogens. ${ }^{286}$ Resort to armed force is however permissible when it is conducted in self-defence under art $51,{ }^{287}$ or if the collective action of military force is authorised by the UNSC under Chapter VII of the UN Char-

S-2/1 A/HRC/3/2 (2006) at [53-55]

${ }^{280}$ UNEP 2009, above n 109, at 37-38; Bunker, above n 5, at 211.

${ }^{281}$ Vöneky, above n 178, at 28.

${ }^{282}$ UNSC 687, above $\mathrm{n} 205$, at [16].

${ }^{283}$ It is subsidiary and indirect because "the rules on the use of force are neither primarily applicable during armed conflict, nor do they intend to protect the environment during armed conflict".Koppe, above $\mathrm{n}$, at 309 .

284 Michael N. Schmitt "Computer Network Attack and the Use of Force in International Law: Thoughts on a Normative Framework" (1999) 37 Colum. J. Transnat'l L. 885 at 886. For a general discussion about use of force in international law, see Christine D. GrayInternational Law and the Use of Force (Oxford University Press, Oxford, 2004).

${ }_{285}$ This article reads: "[a]ll members shall refrain in their international relations from the threat or use of force against the territorial integrity or political independence of any state, or in any other manner inconsistent with the purposes of the United Nations". Charter of the United Nations, art 2(4).

${ }^{286}$ YoramDinsteinWar, Aggression, and Self-Defense(4th ed, Cambridge University Press, Cambridge, 2005) at 99-100.

287 Article 51 reads: "[n]othing in the present Charter shall impair the inherent right of individual or collective self-defence if an armed attack occurs against a Member of the United Nations, until the Security Council has taken the measures necessary to maintain international peace and security. Measures taken by Members in the exercise of this right of self-defence shall be immediately reported to the Security Council and shall not in any way affect the authority and responsibility of the Security Council under the present Charter to take at any time such action as it deems necessary in order to maintain or restore international peace and security". Charter of the United Nations, art 51. 
ter. $^{288}$ It is well established by customary international law that resort to the use of armed force in self-defence must be both proportional and necessary. ${ }^{289}$

Any resort to armed force by states, whether lawful or not, is highly likely to lead to international hostilities. Legal obligations under ius ad bellum are considered to be peacetime obligations because they regulate states' decisions to resort to armed force in times of peace. It is accepted that ius ad bellum and ius in bello are two different branches of law that invoke distinct responsibilities. ${ }^{290}$ However, the application of both of these rules to the events of the 1991 Gulf War presents an interesting and important relationship between when these rules will be considered to have been breached and the legal consequences of such a breach. This is because a belligerent may be held responsible based on its violation of the rules of ius ad bellumfor the consequences of war, including illegal conduct during armed conflict.

In 1991, Iraq's invasion and occupation of Kuwait was determined to be a violation of ius ad bellum. UNSC Resolution 687 affirmed that:

Iraq, (...), is liable under international law for any direct loss, damage, including environmental damage and the depletion of natural resources, or injury to foreign Governments, nationals and corporations as a result of its unlawful invasion and occupation of Kuwait. ${ }^{291}$

Further, in order for a claim arising out of these events to be accepted and reviewed by the UNSC, the claim"must be the result of Iraq's unlawful invasion and occupation of Kuwait" and "the causal link must be direct". ${ }^{292}$ One example of when the causal link will be sufficiently "direct" is where the loss has resulted from "military operations or threat of military action by either side during the period of 2 August 1990 to 2 March 1991". ${ }^{293}$ The word "during" suggests that the main concern is about wartime conduct and not the prewar period when Iraq decided to use force (which is subject to ius ad bellum). The UNSC's approach means that Iraq was held responsible for its illegal conducts during the war based on a violation of ius ad bellum and not ius in bello.

This event has blurredthe distinction of legal responsibility from two branches of law, ius ad bellum and ius in bello. This is due to the fact that Iraq was determined to be the "aggressor" that violated the law on the use of force by unlawfully initiating war;and was consequently found liable for all damage during the war. ${ }^{294}$

This event has also triggered a challenge to theprinciple of equal ap-

${ }^{288}$ Ibid, arts 42-47.

${ }^{289}$ In the Nicaragua Case, the ICJ states: "[s]elf-defence would warrant only measures which are proportional to the armed attack and necessary to respond to it, a rule well established in customary international law". Nicaragua Case, above n 166, at 94. This confirmation was repeated again by the Court in the 1996. Nuclear Weapons Advisory Opinion, above n 141, at 245.

${ }^{290}$ Koppe, above n 9, at 317.Ius ad bellum applies in peacetime and concerns only a state's decision to resort to armed force against another state. If such decision is deemed unlawful under ius ad bellum then the concerned state is responsible for that violation of law. Meanwhile, ius in bello applies in wartime and concerns only a state's military conduct in active armed conflict. If there are violations of any rules of the law of war (ius in bello) then the concerned state is held responsible.

${ }^{291}$ UNSC 687, above $\mathrm{n} 205$, at [16] (emphasis added).

292 The Council excluded losses resulting from the UN trade embargo from this category because this loss does not have direct causal link to the invasion. United Nations Compensation Commission Decision No. 15,Compensation for Business Losses Resulting from Iraq's Unlawful Invasion and Occupation of Kuwait where the Trade Embargo and Related Measures were also a Cause S/AC.26/1992/15 (1993) at [3].

${ }^{293}$ Ibid at [6] (emphasis added).

${ }^{294}$ UNSC 687, above n 205, at [16]. 
plication (or treatment) ${ }^{295}$ of ius in belloin times of war.It seems that,as opposed to equal treatment, in the event of war initiated by violation of ius ad bellum, the application of ius in bellowill turn against the aggressor. This is based on anargument that military activities, such as killing people and destroying property, are originally criminal in nature unless justified by legitimate reasons. In addition, challenges to equal treatment under ius in belloare also based on the maxim of ex iniuriaius non oritur that an entity cannot benefit from rights that result from illegal activities. ${ }^{296}$ Indeed, in 1963, the Institut de Droit International or Institute of International Law conducted a thorough study on this issue and accepted unequal treatment of belligerentsin cases where the UNSC "has labelled one of the parties as 'aggressor'" or in cases of "collective action by UN forces based on a decision of the [UNSC]". ${ }^{297}$

This discriminatory application of ius in bello may have an effect on an aggressor's rights and obligations in times of war, particularly in regards to the continuation of peacetime treaties. The international community accepts that an aggressor state does not have the right to terminate, withdraw from or suspend all peacetime (environmental)obligations for its own benefit as a result of armed conflict. ${ }^{298}$ Consequently, this guarantees that an aggressor state will always continue to be bound by any Multilateral Environmental Agreements (MEAs) they subscribed to during peacetime.

Allocation of state liability for war damage according to its position of unlawful conduct under ius ad bellum has some precedent in the aftermath of World War I ${ }^{299}$ and World War II. ${ }^{300}$ In addition, the idea of holding aggressors liable for war damage in general is supported by many experts. ${ }^{301}$ To some

295 This principle means that belligerents are treated equally without prejudice of whether their resort to armed force under ius ad bellum is lawful or not. See the Four 1949 Geneva Conventions, above $\mathrm{n}$ 34, art 1; The 1977 Additional Protocol I, above n 45, Preamble, paragraph 5.

${ }^{296}$ Dinstein, above n 288, at 156-157.

${ }^{297}$ Koppe, above n 9, at 320 .

298 The 1985 IDI Resolution, above n 197, art 9. It reads: “[a] state committing aggression within the meaning of the Charter of the United Nations and Resolution 3314 (XXIX) of the General Assembly of the United Nations shall not terminate or suspend the operation of a treaty if the effect would be to benefit that state". See also Draft Article 15, The 2011 ILC Draft Articles, above n 197, which reads: "[a] state committing aggression within the meaning of the Charter of the United Nations and resolution 3314 (XXIX) of the General Assembly of the United Nations shall not terminate or withdraw from a treaty or suspend its operation as a consequence of an armed conflict that results from the act of aggression if the effect would be to the benefit of that state".

${ }^{299}$ In the Treaty of Versailles, Germany accepted responsibility: "for causing all the loss and damage to which the Allied and Associated Governments and their nationals have been subjected as a consequence of the war imposed upon them by the aggression of Germany and her allies". Germany also agreed to: "make compensation for all damage done to the civilian population of the Allied and Associated Powers and to their property during the period of belligerency of and as an Allied or Associated Power against Germany, by such aggression by land, by sea, and in general by all damage as defined in Annex 1 hereto". Consequently, the parties of this treaty established an Inter-Allied Reparation Commission under art 233. The purpose of this Commission was to assess the claims and determine the quantity of damages for compensation. Treaty of Peace with Germany (signed 28 June 1919) (1919) 13 AJIL 151, arts 231-233.

300 The Peace Treaties concluded in 1947 following WWII charged the defeated states with crime of aggression that have taken part under the aegis of Germany. H. Lauterpacht "The Limit of the Operation of the Law of War" (1953) 30 BYIL 206 at 235.

${ }^{301}$ Koppe, above n 9, at 327. Fitzmaurice stated in 1948: "[ $t$ ] he principle that states in the position of wrongdoers as a result of their aggression, are responsible for the ensuing damage, irrespective of any treaty provision, may well be a useful one to establish". Gerald G. Fitzmaurice "The Juridical Clauses of Peace Treaties" (1948) 73(II) Collected Courses of the Hague Academy of International Law 259 at 326. 
degree, certain of these experts have been influenced by the experience in the 1991 Gulf War. They are Low and Hodgkinson in 1995, ${ }^{302}$ Boelaert-Suominen in $1996,{ }^{303}$ Greenwood in $1996,{ }^{304}$ Gattini in $2002,{ }^{305}$

and Ronen in 2008. ${ }^{306}$

In terms of compensation for environmental damage as a consequence of violations to the rules ofius ad bellum, the experience of the 1991 Gulf War has become a landmark case, leading to the first instance of compensation being consideredavailable for environmental damage arising as a result of a state's unlawful conduct of aggression. ${ }^{307}$ Resolution 687 has been described as "unprecedented" ${ }^{308}$ and "historically unique". ${ }^{309}$ In contrast, if art 2(4) had not been used as the legal basis for environmental compensation claims and claimants were required to prove direct loss under the laws of armed conflict, it would make the evidentiary process much more difficult. ${ }^{310}$

Ultimately, Resolution 687 confirmed that a state which violates ius ad

${ }^{302}$ Low and Hodgkinson conclude that: "[v]iolations of ius ad bellum should be distinguished from violations of ius in bello because a party that violates ius ad bellum may be held responsible for all damages caused by such a war regardless of whether it acted lawfully in the context of ius in bello. Compensation for violations of ius ad bellum is thus separate from compensation for violations of ius in bello", above 15, at $412-413$.

${ }^{303}$ Boelaert-Suominen argues that: "[g]eneral international law on compensation for war damage clearly establishes the principle that aggressor states are liable to pay reparation for damages resulting from breaches of the ius ad bellum. Reparations may cover damage to public and private property, loss of life and injuries to civilians and generally at least part of the war costs of the victorious states. However, the exact range of claims to be covered by the reparation regime, the amount of reparations and the modalities of implementation depend on particular terms of the peace treaties". Sonja Boelaert-Suominen "Iraqi War Reparations and the Laws of War: A Discussion of the Current Work of the United Nations Compensation Commission with Specific Reference to Environmental Damage during Warfare" (1996) 50 Austrian J. Pub. \& Int'l L. 225 at 308.

${ }^{304}$ Greenwood observes: "[a] state is liable, in principle, to pay compensation for damage, including environmental damage, caused by an unlawful resort to force. (...) State responsibility here flows from a breach not of the ius in bello but of ius ad bellum", above n 176, at 403 .

${ }^{305}$ According to Gattini, the starting point of Iraq's liability under Resolution 687 was "[t]he existence in contemporary international law of a norm which post bellum permits or even demands the liability of the aggressor state, charging it with an obligation to make good not only the entire amount of damage caused by itself, but also damage arising from the legitimate exercise of self-defence by the state that is the victim of the aggression". Andrea Gattini "The UN Compensation Commission: Old Rules, New Procedures on War Reparations"(2002) 13 EJIL 161 at 173.

306 Ronen observes: "[ $t$ ] he attachment of responsibility for the illegal occupation in a manner which creates liability for acts carried out in compliance with the law of occupation may serve as a deterrent for illegal occupants. (...) If the responsibility of the occupant accrues regardless of the legality of the actions, a realistic approach cannot but admit that an occupant is as likely to expand its illegal acts (because it is liable in any case), as it is to withdraw from territory occupied illegally". Yael Ronen "Illegal Occupation and Its Consequences" (2008) 41Israel L. Rev.201 at 232.

307 Catherine Tinker argues that the Resolution was the "first determination under international law of a state's liability for harm to the environment itself, apart from direct injury to people or property, and for the depletion of natural resources". Catherine Tinker "Environmental Security' in the United Nations: Not a Matter for the Security Council” (1992) 59 Tenn. L. Rev.787 at 789.

${ }^{308}$ Identical Letter dated 6 April 1991 from the Permanent Representative of Iraq to the United Nations addressed respectively to the Secretary-General and the President of the Security Council S/22456 (1991) at [2].

${ }^{309}$ Low and Hodgkinson, above n 15 , at 455.

310 Tiffany Y. Lee "Environmental Liability Provisions under the UN Compensation Commission: Remarkable Achievement with Room for Improved Deterrence” (1998) 11 Geo. Int'l Envtl L. Rev. 209 at 218-219. 
bellum may be held responsible for all damage, including environmental damage, caused by the war, regardless of whether there was any violation of ius in bello. ${ }^{311}$ This resolution also shows that ius ad bellum, hitherto usually considered as part of international law's peacetime obligations, has significant potential for addressing environmental damage related to armed conflict.

Further, in terms of future development, the fact that the UNSC held the aggressor state in the 1991 Gulf War responsible in this manner likely indicates thatthe UNSC will act similarly in subsequent cases. ${ }^{312}$ Such a precedent has been considered to provide significant deterrent effects. ${ }^{313}$ In addition, protection proffered by ius ad bellummay become a safety net which could overcome some deficiencies in the protection of the environment under ius in bello. ${ }^{314}$

\section{Conclusion}

As far as environmental protection during armed conflict is concerned, IHL provides significant direct and indirect legal protection, which comes from treaty and customary laws. Given the wide array and significant number of existingrules that protect the environment within IHL, it is perhaps less important to have a new, specific international agreement focusing on environmental protection during times of war.

The development of environmental protection within the law of war may be broadly divided into two time-periods: before and after the 1970s. Widespread concern over the global environment in general only began in earnest in the 1970s. Such growing concern also applied in the area of armed conflict. It has been noted that the word "environment" does not occur in any IHL treaty prior to 1977 . However, this does not mean the environment was not protected during times of war, but rather that such protection was found in different forms and contexts. Prior to 1977, protection of the environment was afforded in more general statements of principle, ${ }^{315}$ and was often incidental to human protection. ${ }^{316}$ After 1977, in contrast, provisions in IHL were adopted which specifically or expressly protected the environment.

In addition, protection of the environment proffered by the law of war may be strengthened by the fact that there are also relevant international peacetime rules which protect the environment and remain valid during times of war. With the identification of such rules, it may be submitted that the environment is afforded an additional layer of legal protection during armed conflict. Therefore, belligerent states no longer have any leeway to escape their duty of taking into account environmental factors when conducting military operations.

Generally, the applicability of peacetime treaty provisions during wartime is based on the widely acknowledged principle that the event of armed conflict does not ipso facto suspend or terminate the pre-existing

\footnotetext{
311 Low and Hodgkinson, above n 15, at 456,

${ }^{312}$ Greenwood, above n 176, at 407; Low and Hodgkinson, ibid, at 477-479; Bunker, above n 5, at 209.

${ }^{313}$ Greenwood, ibid, at 412.

${ }^{314}$ Koppe, above n 9, at 333 .

${ }^{315}$ Roberts, above n 110, at 229.

316 Stone, above n 61, at 21 .
} 
treaties. ${ }^{317}$ Some categories of treaties have been argued to remain applicable between belligerents during times of war. These are treaties whose objects are largely unaffected by the advent of war between parties to the agreements and/or which the parties intended to continue during such periods. Of these categories, environmental protection during wartime may be found in two branches of law: international human rights law and international environmental law. In addition to these two fields of law, rules from ius ad bellum(or the law on the use of force) also provide significant protection from environmental harm during times of war, despite their primary applicability during peacetime. Identification of relevant rules from these laws has shown that peacetime obligations provide additional layers of protection for the environment during war.

Provisions from international human rights law are considered valid both during peacetime and wartime. This is because the object of these laws is to enforce basic universal human protections, which is also the main goal of the law of war in general. Specific environmental protection is found in the general acknowledgement of international declarations ${ }^{318}$ and reports of human rights commissioners. ${ }^{319}$ The most relevant provision from human rights law that offers explicit protection to the environment is art 12 of the ICESSome treaties within international environmental law potentially remain valid during wartime by way of analogous approach. An environmental treaty may continue to apply in times of armed conflict if it has the aim of serving the interests of the international community as a whole. In relation to this, it is proposed that two categories of environmental treaty remain valid during wartime and thus bind belligerent states: treaties protecting areas beyond national jurisdiction and treaties protecting "common goods".

The provisions of the law on the use of force, or ius ad bellum, also provide significant protection of the environment during wartime, albeit in an indirect way. Protection under this regime is provided by the fact that aggressor states are held accountable for paying compensation for war consequences, including environmental damage. This kind of compensation finds its precedent in previous cases of armed conflict, such as the World Wars and the 1991 Gulf War.

These peacetime obligations form an important group of legal norms which address environmental protection in relation to armed conflict. Even though these peacetime obligations do not regulate a state's conduct during armed conflict, "they reinforce civil liability and help define criminal responsibility under the laws of war". ${ }^{320}$ They also provide additional legal mechanisms for responsible belligerents to repair or compensate another state for any environmental damage resulting from their unlawful conduct. Further, these peacetime obligations could play a crucial role in filling the gaps in the general principles of law recognised by nations, in cases when international conventions and customary international law fail to address a particular problem. ${ }^{321}$

Finally, it is important to emphasise that the environment is sufficiently

${ }^{317}$ Indeed, subject to the law of neutrality, treaty relationships between belligerents and neutral states are largely unaffected and remain valid. See above at [2.2.1.5].

318 The Stockholm Declaration, above n 173, at [1]; The Rio Declaration, above n 215, principle 1.

319 The 1994 Ksentini Report, above n 216, at 27-30, 74 (principles 1 and 23).

${ }^{320}$ Sharp, above n 62, at 28.

321 Ibid. 
protected by international law during international hostilities. It is a fact that there are significant numbers of international rules that protect the environment in a comprehensive manner during wartime which are sourced not only from wartime laws but also peacetime obligations that bind state belligerents. It is also important to understand that this means that any belligerent party that has caused environmental damage in an armed conflict should be held accountable for its unlawful conduct 